\author{
ROBERT J. GORDON* \\ University of Chicago and the \\ National Bureau of Economic Research
}

\title{
Inflation in Recession and Recovery
}

The cruel choice between two evils, unemployment and inflation, has become the major economic issue of the day. ${ }^{1}$

THE INTERVAL FROM 1969:3 To 1970:4 qualifies as a full-fledged economic slowdown in which the official unemployment rate increased by 59 percent. But in the first year of every previous U.S. postwar recession, the rate of inflation was lower than it was in the last expansion year, while the rate of inflation was more rapid in 1970 than during any part of the previous business expansion. ${ }^{2}$ This paper develops wage and price equations that attempt, first, to explain why inflation accelerated in 1970 rather than slowing as it did during past recessions; second, to isolate the relative role of prices and wages in the 1970 episode; and third, to form predictions of wage and price behavior during the next ten years. In particular, the paper attempts to predict the response of the rate of inflation to alternative paths of economic recovery - that is, to estimate how much more rapidly prices would

* I am grateful to Thomas D. Henrion for helping me prepare the computer runs. The paper was made possible by the contributions of the National Bureau of Economic Research for research assistance and of the Department of Economics of the University of Chicago for computer time. I wish to acknowledge, besides the help received from members of the Brookings panel, the comments of Milton Friedman, and other members of the Money and Banking Workshop at the University of Chicago, on an earlier version of this paper.

1. James Tobin and Leonard Ross, "Living with Inflation," The New York Review of Books, Vol. 16 (May 6, 1971), p. 23.

2. During the five expansionary quarters between $1968: 2$ and 1969:3, the nonfarm private deflator increased at an annual rate of 4.2 percent, while during the five quarters between 1969:3 and 1970:4, the deflator increased by 5.2 percent. For comparable figures during previous recessions, see my "Prices in 1970: The Horizontal Phillips Curve?" Brookings Papers on Economic Activity (3:1970), p. 449. 
increase if full employment were to be attained swiftly rather than gradually. In addition, the short- and long-run tradeoffs between inflation and unemployment are calculated. The results show that in the long run a given reduction in the unemployment rate causes a greater increase in the rate of inflation than most previous research has suggested; nevertheless, the data do not support the "accelerationist" hypothesis that there is no long-run tradeoff.

\section{Inflationary 1970: Was It a Surprise?}

The Phillips curve pictures a widely accepted hypothesis that the rate of inflation is inversely dependent on the rate of unemployment. The simplest version of the hypothesis makes no distinction between long-run and shortrun Phillips curves; the economy is always on "the" curve and experiences an immediate reduction in the rate of inflation whenever, as in 1970, the unemployment rate rises. A more sophisticated approach treats the Phillips curve as a long-run equilibrium relationship from which the economy can diverge in the short run. In particular, if wages and prices adjust slowly to changes in economic conditions, an increase in the unemployment rate is not accompanied by an immediate reduction in the rate of inflation. Eventually, however, the rate of inflation will decline after sufficient time has passed for the lagged effects of the higher unemployment rate to work their way through the economy.

In an earlier paper, I presented one version of a "dynamic Phillips curve" in which inflation was determined by the interaction of separate wage and price equations. ${ }^{3}$ How surprising was 1970 when viewed against their predictions? Using actual price changes to help predict wages, the wage equation tracked the first half of 1970 well, but underpredicted the rate of wage increase in the last two quarters by an average of 1.0 percentage point at an annual rate. Using actual wage changes in the price equation, it underpredicted the annual rate of price increase by an average of 1.1 percentage points during the last three quarters of the year. Full predictions, based on predicted rather than actual values of both variables in both equations, result in a widening underprediction of the rate of price increase, reaching 2 percentage points in the fourth quarter.

3. Robert J. Gordon, "The Recent Acceleration of Inflation and Its Lessons for the Future," Brookings Papers on Economic Activity (1:1970), pp. 8-41. 
In short, the continued acceleration of inflation in 1970 was indeed a "surprise" when compared with these predictions. This paper seeks to develop refinements to these earlier wage and price equations that will improve both the fit to historical data and the explanation of developments in 1970.

Like most other recent research, the model developed here postulates that the primary force "driving" the rate of inflation is the determination of wages in the labor market. The price equation is based on the hypothesis that in the long run the relative shares of wage and nonwage income are constant and that the price level is thus "tied" to labor cost; the purpose of the price equation is then to describe temporary deviations of the distribution of income from this long-run constant relationship. The dominant role this model assigns to wages in the inflation process justifies the disproportionate emphasis that it receives in the following discussion.

\section{The Determination of Wages}

The theory of wage determination used here is similar in its general features to the approach taken by most previous econometric research. The primary current force that pulls the wage level upward (relative to "standard" productivity) is an excess demand for labor. When workers are in short supply, firms raise wage rates both to bid workers away from other firms and to induce new entrants into the labor force. Workers do not evaluate wage offers by employers in a vacuum, however, but measure them against the wage they expect to receive if they remain in their present jobs and the expected price level of the goods they will be able to buy with them. Thus the second major force pushing upward on wage rates is the expected rate of increase in prices and wages. Even without current excess demand for labor, the average wage rate would be pushed up faster than the trend increase in productivity if the price level were expected to rise rapidly. ${ }^{4}$ In

4. For a theoretical labor market model in which the primary "pushing" force is the expected increase in wages, see Edmund S. Phelps, "Money-Wage Dynamics and LaborMarket Equilibrium," Journal of Political Economy, Vol. 76 (July/August 1968), pp. 678-711. For a model in which the expected increase in prices plays a dominant role, see Milton Friedman, "The Role of Monetary Policy," American Economic Review, Vol. 58 (March 1968), pp. 1-14. A hybrid model combining elements of both approaches and several other innovations is contained in a monograph that I am currently preparing for the National Bureau of Economic Research. 
short, the basic variables in most wage equations fall into two classes, intended to measure either (1) the "pull" of the labor market, or (2) the "push" of price expectations. Much of the controversy in the field centers on the way to measure excess labor demand and price expectations; the selection among the competing methods that make theoretical and intuitive sense depends on the verdict of the empirical data.

\section{ALTERNATIVE MEASURES OF EXCESS LABOR DEMAND}

The aggregate unemployment rate, the most widely publicized measure of labor market tightness, is subject to several important criticisms that have led George Perry, myself, and others to suggest alternative measures.

The unemployment inverse $(1 / U)$. Frictional and structural unemployment set a floor to the unemployment rate, but there is no upper limit to the degree of excess demand that can accompany this minimum unemployment rate. Thus the relationship of excess demand and hence wage increases to the unemployment rate is usually assumed to be convex to the origin. In an attempt to approximate this convexity, the inverse of the unemployment rate has been the measure of labor market pressure most frequently used in previous research.

The vacancy rate $(V)$. Since the major current determinant of wage increases is assumed to be net excess labor demand, the rate of unemployment, which measures excess labor supply, should in principle be supplemented by a measure of excess labor demand. Unfortunately, the absence of a comprehensive vacancy measure for the postwar United States has inhibited this approach, but I propose to use, as a rough approximation to a vacancy rate, the number of "nonagricultural job openings unfilled" (a series collected by the U.S. Manpower Administration) divided by the civilian labor force. The obstacle to using this series is its partial coverage, but a workable assumption is that the ratio of "unmeasured" to "measured" vacancies is constant. If so, the vacancy rate $(V)$ can be multiplied by a constant selected to make the net excess demand measure $(V-U)$ equal to zero in a period when labor markets appear to be "in balance." 5

5. I assumed that labor markets were "in balance" in 1965:2, requiring that the vacancy rate be multiplied by 11.0 . This arbitrary choice serves only to scale the vacancy rate to the same order of magnitude as the unemployment rate, but has no effect on the final results, since $V_{t}$ and $U_{t}$ are entered separately into the regressions below in order to allow the computer to determine the "true" contribution of each variable to labor market tightness. 
The total unemployment rate of manhours $\left(U^{L}\right)$. In my first article for the Brookings panel, I employed a measure of unemployment that adjusts the official index for both the rate of "disguised unemployment" and "the unemployment of hours." Disguised unemployment $\left(U^{D}\right)$ estimates the number of individuals not in the labor force, and therefore not officially counted as unemployed, who would accept jobs if they were available. Unemployment of hours $\left(U^{H}\right)$ measures deviations of actual hours worked per week from an estimate of the hours that would be worked at full employment. Deviations between the official $(U)$ and "total" unemployment rates $\left(U^{L}=U+U^{D}+U^{H}\right)$ were particularly marked in 1969, when labor demand was so intense that employers filled jobs substantially by drawing new entrants into the labor force; the official unemployment rate declined between 1968 and 1969 only from 3.63 to 3.53 percent, while the total rate declined from 3.73 to 2.93 percent. $^{6}$

The weighted unemployment rate $\left(U^{*}\right)$. Perry has suggested that the "effi. ciency units" of effective labor supply contributed by unemployed individuals of various age-sex groups depend both on the average hours per week typically worked and the average wage typically received by members of each group. A prime-age male capable of filling a job paying $\$ 4.00$ per hour for a forty-hour week makes a greater contribution to effective labor supply than a teenager who typically fills a $\$ 1.50$-per-hour job for fifteen hours per week, but both are counted as one body in the official unemployment statistics. To remedy this problem Perry has calculated a "weighted unemployment rate" and has provided his data for use here. ${ }^{7}$

Unemployment dispersion ( $D U$ ). Since the relationship between excess demand and unemployment is usually assumed to be convex to the origin, the degree of excess demand associated with a given average unemployment rate is higher if unemployment rates for subgroups of the labor force are widely dispersed (indicating that workers in the different subgroups are not perfect substitutes) than if they are all equal to the average rate. Perry has constructed a dispersion measure along the age-sex dimension of the labor force, and his index has been used here. ${ }^{8}$ Other dispersion measures could

6. The calculations of the total unemployment rate have been revised in the past year and are described in Appendix C. The total unemployment series $\left(U^{L}\right)$, but not the vacancy rate $(V)$, reveals 1969 as a year of intense labor demand, suggesting that the two measures pick up evidence of excess labor demand in different occupations or areas.

7. George L. Perry, "Changing Labor Markets and Inflation," Brookings Papers on Economic Activity (3:1970), pp. 411-41.

8. Ibid. 
also be developed along geographical or industrial dimensions, but this task has not been undertaken here. Both of the Perry measures, $U^{*}$ and $D U$, basically test the hypothesis that a given official unemployment rate was associated with a higher level of net labor demand in the late 1960s than in the mid-1950s because the unemployment rate of young workers and adult women was much higher relative to the unemployment rate of prime-age males in the recent period than in the earlier period. ${ }^{9}$

For standard statistical methods to be able to discriminate among them, the alternative measures of labor market tightness must exhibit significantly different patterns of behavior over postwar business cycles. The major differences among the series are as follows: For much of the period the actual unemployment inverse $(1 / U)$ and weighted unemployment inverse $\left(1 / U^{*}\right)$ follow virtually the same path, but $1 / U^{*}$ indicates considerably more labor market pressure than $1 / U$ in 1964-69, particularly in 1968-69. The vacancy rate $(V)$ follows the cyclical path of $1 / U^{*}$ but indicates somewhat tighter markets in the 1957-67 period, especially in 1966. The total unemployment inverse $\left(1 / U^{L}\right)$ behaves quite differently and indicates much weaker labor markets than $1 / U$ during the entire period 1957-66, and a much stronger labor market in 1969. Starting in the mid-1950s, the dispersion measure $(D U)$ rises relative to $1 / U$, indicating tighter labor markets at any given unemployment rate, with the gap opening especially rapidly in 1963-64.

\section{THE MEASUREMENT OF PRICE EXPECTATIONS}

The determination of price expectations has become an increasingly popular subject for research in recent years as the accelerating pace of U.S. inflation has made the topic more relevant. Virtually none of the published papers on wage determination, however, devotes more than cursory attention to the problem. The wage equations developed here allow the data to determine the answers to three different sets of issues.

The length of the lag. Most commonly, price effects have been introduced by including changes in the consumer price index as an explanatory variable in the wage equation with a one-quarter lag. If its result is interpreted as an expectation variable, this practice implies that individuals always expect the

9. An approximation to the Perry hypothesis could be tested directly through the use of the official unemployment rate for a "prime" group-for example, married malesas a measure' of labor market tightness. Experimental tests of this measure in wage equations like those of Table 1 below were not fruitful. 
rate of change of prices to be what it was in the previous quarter, a curious kind of myopia. This implication conflicts with a growing body of evidence that price expectations, in so far as they are revealed in financial markets by the behavior of interest rates, are determined by a considerably longer history of past price changes. Here I test several alternatives, comparing the one-quarter lag with a longer pattern of lag coefficients on past price changes as determined in equations explaining the market interest rate (see Appendix A). ${ }^{10}$ The final price expectations variable, although based on the interest rate equations, has a pattern of lag coefficients very similar to that obtained when a long series of past inflation terms is included directly in the wage equation.

The appropriate price variable. In previous research, the consumer price index (CPI) generally has been chosen as the appropriate price variable for inclusion in a wage equation, on the reasonable grounds that it is widely publicized and enters into cost-of-living clauses in wage bargains. But the use of the CPI creates a problem for wage-price models designed to predict inflation. If the CPI helps to predict wages and wages help to predict the nonfarm private deflator (NPD), the price variable that the model attempts to explain, the circuit must be closed with a third equation relating the CPI to the NPD, a link that appears impossible to estimate properly at present. ${ }^{11}$ A simple and direct expedient is the use of the deflator for personal consumption expenditures (PCD) in the wage equation. This is desirable not only because the PCD can be more easily related to the NPD than can the CPI, but also because the CPI may contain an upward bias not present in the PCD. ${ }^{12}$ The choice between the CPI and the PCD is important, because

10. The one-quarter lag has been used most recently by Perry, ibid. For a discussion of the role of price expectations in interest rate equations, see my "Econometrics of Price Determination: Discussion," in Otto Eckstein (ed.), The Econometrics of Price Determination, forthcoming conference volume.

11. The CPI has caused similar difficulties before. See the discussion of an attempt to explain the relation between the NPD and the CPI on pp. 37-38 of my article, "Recent Acceleration of Inflation."

12. There is a marked discrepancy between the rates of increase of the PCD and the CPI in the 1967-70 period which can be traced mainly to the differing treatment of housing. Here the PCD is preferable, since the CPI (a) treats all price increases in used houses as a pure increase in the cost of living to home purchasers while totally ignoring the offsetting benefit of capital gains to home sellers, and (b) fails to adjust rising mortgage interest rates either for the vast numbers of homeowners who hold existing mortgages at fixed rates or for the contribution to the interest rate increase of anticipated capital gains by new borrowers. 
the estimated coefficients on the price expectations variable in the wage equation tend to differ in each case, as noted below.

Effect of prices on the demand for labor. A profit-maximizing firm attempts to equate the nominal wage and the value of labor's marginal product, which increases when the firm finds it can sell its output at a higher price. In a period of excess commodity demand, when (as is shown below in the discussion of price determination) firms raise the price level relative to labor cost, their demand for labor increases and they are willing to pay a higher wage. The same result occurs, even if firms do not take the initiative in raising wages, when union leaders respond to a firm's increased profits by demanding higher wage increases than they would otherwise. In the wage equations presented below, this "marginal-revenue-product demand effect" is tested by including as an additional explanatory variable the difference between the rate of increase in product prices, measured by the NPD, and consumer prices, measured by the PCD. If the coefficient on this variable is positive, the effect of prices on wages works through this second channel as well as through the price expectations mechanism; an increase in total product price relative to consumer prices could raise wages only through the product demand effect, since there would be no direct impact on the price expectations of consumers.

\section{OTHER DETERMINANTS OF WAGE CHANGE}

In addition to the major role played by labor markets and price expectations in this analysis of wage determination, other factors are tested for their effects.

Guideposts. Following the recent tradition in the wage determination literature, I shall test the significance of a dummy variable in the final wage equation to represent the effect of the Kennedy-Johnson wage-price guideposts. ${ }^{13}$

Direct taxes. The incidence of taxes on labor income depends on the effect of the tax on labor's pretax share. Workers suffer the full burden of the tax unless their pretax income share increases in response to a rise in the tax rate. But, since the real pretax wage that employers can afford to pay de-

13. The definition of the guidepost dummy in Appendix $C$ is based on a suggestion by George Perrý. 
pends on labor's marginal product, workers are likely to bear the full tax burden in the long run, except in special circumstances. ${ }^{14}$ In the present wage-price model, the pretax distribution of income is determined by the price equation; there it turns out that the burden of both social security and personal income taxes is borne ultimately by workers. ${ }^{15}$

But regardless of the long-run effects of direct taxes, a change in tax rates may have a substantial short-run impact on the rate of inflation. If the supply of labor offered is greater at higher anticipated real wages-reckoned as the after-tax wage rate divided by the price level that workers anticipate during the contract period - an increase in the rate of direct taxation on labor income raises the before-tax wage that will be necessary to induce workers to supply a given quantity of labor. The consequence of the upward shift in the supply schedule caused by the increase in the tax rate will be an increase in the real wage before taxes, a consequent reduction in the quantity of labor that firms can afford to hire, and an increase in the unemployment rate. If policy makers offset the increase in unemployment by expansive monetary or fiscal policy and return the unemployment rate to its original level, the price level will increase by enough to return the before-tax real wage to its original level, and the ultimate effect of the tax increase will be an increase in both nominal wages and prices with no change in the distribution of income. ${ }^{16}$

Of course, an increase in the direct tax rate need not be inflationary. If the supply of labor is inelastic with respect to changes in the real wage, an

14. Regardless of the elasticity of labor supply to changes in the real wage, labor's share is constant if the elasticity of substitution between labor and capital in the production function is unity. A tax increase raises the before-tax real wage, which (with competitive factor pricing) reduces employment until the marginal product of labor has risen to the higher real wage. When the elasticity of substitution is unity, the reduction in labor input exactly balances the higher real wage and leaves labor's share unchanged; on the same assumptions, labor's share increases when the elasticity of substitution is less than unity. For evidence supporting a unitary elasticity, see the discussion of price determination below.

15. For evidence from international cross-section data that labor bears the entire burden of the social security tax, that is, both the portion paid by workers and the portion paid by employers, see John A. Brittain, "The Incidence of Social Security Payroll Taxes," American Economic Review, Vol. 61 (March 1971), pp. 110-25.

16. For a similar argument, which distinguishes between the temporary effect of the corporation income tax on the rate of inflation and its long-run lack of effect on the distribution of income, see my "The Incidence of the Corporation Income Tax in U.S. Manufacturing, 1925-62," American Economic Review, Vol. 57 (September 1967), p. 754. 
increase in the tax rate will be borne by labor immediately without any change in the nominal wage or in employment. The absence of any significant change in the labor force participation rate of adult males during the postwar period suggests that this key labor force group may have an inelastic supply curve. ${ }^{17}$ The supply curve for labor may even be negatively sloped if the income effect of a change in the real wage dominates the substitution effect. In this case, the short-run effect of a tax rate increase would be deflationary. Finally, the labor supply offered by workers could in principle depend on the before-tax rather than the after-tax real wage if workers treat the government spending financed by the tax revenue as part of their incomes. This factor is probably not important in fact, since the major changes in personal income tax rates in the United States in 1964 and 1968 were associated with stabilization policy rather than specific changes in expenditures, while changes in social security tax rates, which often occur simultaneously with increases in social security benefits, are paid by individuals other than those who receive the benefits.

Since the theoretical analysis of the inflationary impact of a change in direct tax rates is inconclusive, and since adequate empirical evidence on the shape of the labor supply curve is unavailable, the wage equation allows the empirical data to determine the impact of changes in direct taxes on the wage rate. Separate coefficients are estimated for the impact of taxes paid by employers, $T_{s}$ (the effective rate of employers' social security contributions) and for taxes paid by employees, $T_{e}$ (the effective rate of the employee portion of the social security tax and of the personal income tax). For each kind of tax, the tax variables are expressed as growth rates in $1 /(1-T)$, where $T$ is defined as the average tax rate. This permits the coefficients estimated in the wage equation to be interpreted as tax-shifting parameters; they give the percentage change in wage rates resulting from a 1 percent change in $1 /(1-T) .{ }^{18}$ Because wage negotiations take place at intervals and are not continuous, so that tax rate changes may take a substantial length of time to affect them, both current and lagged tax change variables are tested in the equations estimated below.

17. While there is a significant secular downward trend in nonfarm private hours worked during the postwar years, the reduction has been mainly in industries like retail trade in which the share of women employees is high, while none has appeared in the hours of manufacturing production workers.

18. Specifically, the rate of growth of the pretax wage rate is a linear function of the coefficient on the tax term times the rate of growth of $1 /(1-T)$. 
The short-run tax-shifting parameters could have important consequences for the theory of stabilization policy. A shifting parameter greater than zero implies that a tax increase designed to raise the unemployment rate in order to reduce the rate of inflation will, in addition, raise the price level associated with any given path of unemployment. In this case a movement from a low unemployment rate to a higher unemployment rate engineered by tight monetary policy (assuming that it has no similar unfavorable consequences) would be associated with less inflation than the same unemployment path engineered by tight tax policy. ${ }^{19} \mathrm{~A}$ corollary in the 1971 economic situation would be that a low-tax, tight-money mix would lower the rate of inflation associated with any given unemployment rate, as compared with an easy-money, high-tax policy. On the other hand, zero estimates of short-run tax-shifting parameters imply that fiscal policy has no direct influence on the Phillips curve and affects prices only indirectly through its impact on output and unemployment.

\section{WAGE AND PRICE DATA}

A perennial problem in U.S. wage research is the erratic behavior of the data on compensation per manhour $(C M H)$. There are large measurement errors in the series, due partly to the collection of the compensation and manhours data by two different government agencies following different procedures. A further problem is that the $C M H$ series measures not only changes in wage rates, which are the concern of this paper, but also changes in average compensation arising from fluctuations in output between highwage and low-wage industries and in the percentage of hours paid at overtime rates. To circumvent these problems a new aggregate wage index has been constructed from underlying data on average straight-time hourly earnings by industry, ${ }^{20}$ using fixed 1963 industry weights in aggregating. Changes in the new fixed-weight index $(w)$ are caused only by changes in ac-

19. This analysis must be qualified to the extent that the higher real interest rate that accompanies tight money raises capital costs and is passed forward in the form of higher prices. This effect may be of minor importance, particularly for a temporary increase in the interest rate that raises the cost of new borrowing but not of the existing liabilities of the firm. In any case, it is not taken into account in the price equation below, and thus is not measured quantitatively in this paper.

20. The choice of 1963 weights reflects the central position of this year in the sample period. But wage indexes were also calculated with 1957 and 1967 weights with no noticeable alteration in the rate of change of the aggregate index. 
tual wage rates, not by changes in industry mix or overtime hours. ${ }^{21}$ Figure 1 compares changes in the new $w$ series with changes in $C M H$. Changes in the new series seem much more reasonable than those in $C M H$; in particular, the new series indicates that wage changes were about the same in 1956 as in 1957, and in late 1968 as in 1969, unlike the old series, which displays puzzling peaks in 1956 and $1968 .{ }^{22}$ A close study of the new series raises the possibility that some of the fluctuations in $C M H$ may be statistical aberrations. The increase in $C M H$ relative to $w$ shown in Figure 1 displays pronounced peaks in even-numbered years, particularly 1956, 1960, 1964, 1966, 1968, and 1970. There are noticeable troughs in 1955, 1965, and 1969. Government statisticians should investigate the possibility that there is a simple source of this peculiar behavior, such as different procedures for handling weeks that overlap different years. ${ }^{23}$ In order to illustrate the effect of using $w$ in place of $C M H$, the first wage equation presented below is fitted using both the $C M H$ and $w$ series. ${ }^{24}$

While the new wage series is preferable to $C M H$ in a study of wage determination, its partial coverage may be undesirable in a study of price determination. The $w$ index covers both blue-collar and white-collar "production and nonsupervisory workers," about four-fifths (47.9 million in 1970) of all employees in private nonfarm industries. But it excludes all income received by managerial, supervisory, and professional employees, and for those persons covered it excludes commissions, bonuses, tips, income in kind, and

21. To adjust the fixed-weight wage index for fringe benefits, $w$ was multiplied by the ratio of total compensation of employees to wage and salary income, from the U.S. national income accounts. Changes in overtime outside of manufacturing are not taken into account, since no overtime data exist for the nonmanufacturing sector.

22. Perry is particularly disturbed by the 1968-69 behavior of $C M H$ : "It is hard to think of any model, based on any view of the inflation process, that would not predict some speedup of wage changes during 1969." See "Changing Labor Markets," p. 430.

23. In an equation that attempts to explain the four-quarter rate of change in the $C M H / w$ ratio as a function of lagged changes in output (since overtime and executive bonuses, which should be sensitive to output, are included in $C M H$ but not in $w$ ), a significant coefficient is obtained on a dummy variable, $D_{E}$, which equals 1.0 in even years:

$$
\begin{gathered}
g_{(C M H / w)_{t}}=-0.0087+0.0065 D_{E_{t}}+0.2211 g_{Q_{L}} \\
(-4.1) \quad(4.8) \\
R^{2}=0.454, \text { Durbin-Watson }=0.68, \text { sample period }=1954: 1-1970: 4, \\
\text { growth rates expressed as four-quarter changes. }
\end{gathered}
$$

24. As a parallel to the fixed-weight wage index, in all regressions the nonfarm private deflator is a fixed-weight index of the deflators for fifteen major components of GNP. 


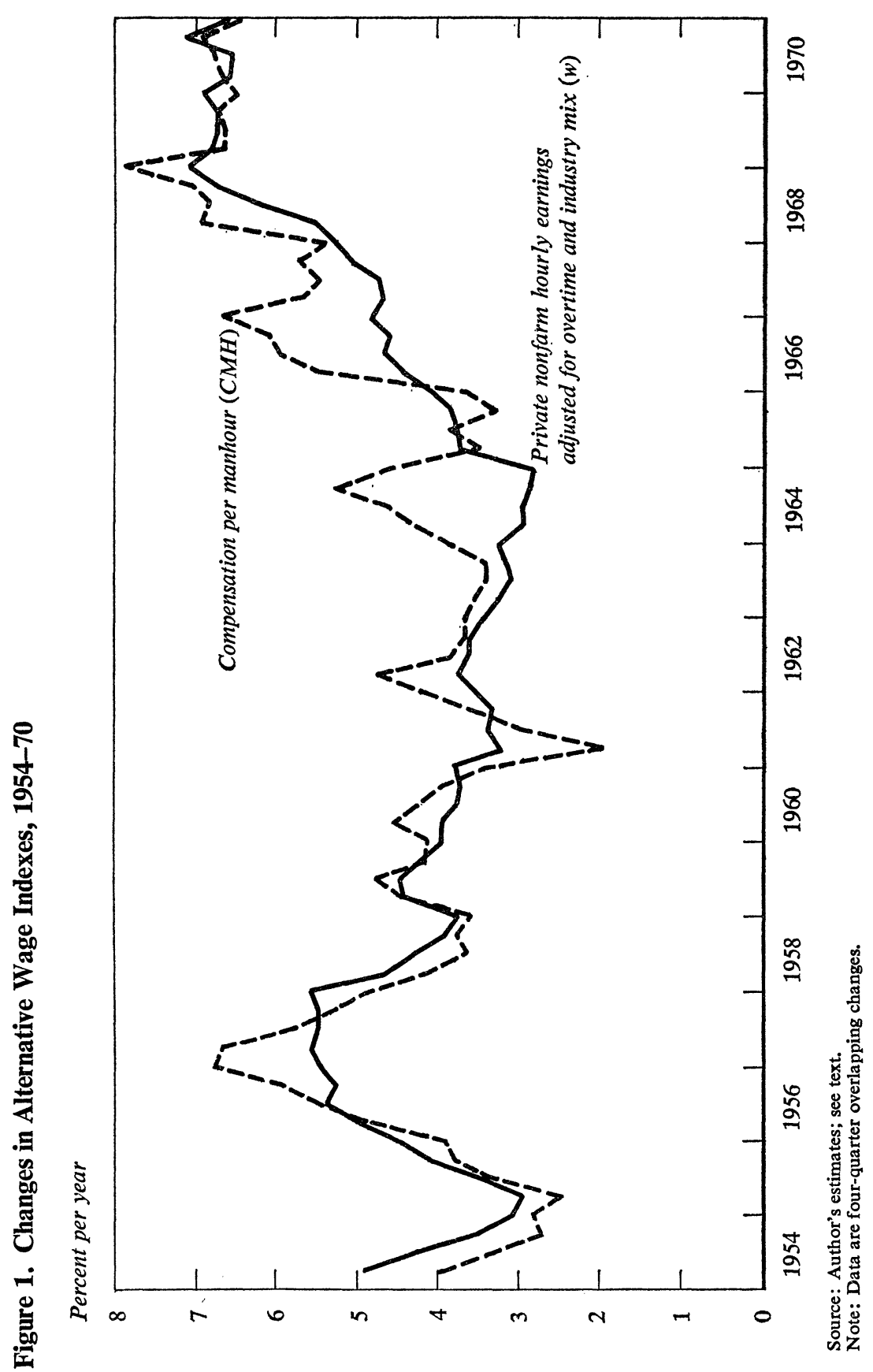


overtime wages. ${ }^{25}$ If pricing decisions compensate even partially for changes in these excluded elements, the ratio of $C M H / w$ is a determinant of the price level and should be included in the price equation developed below.

\section{ANALYSIS OF FITTED WAGE EQUATIONS}

To summarize the discussion to this point, the fitted wage equations in this paper incorporate several new features, which will be tested in comparison to approaches suggested heretofore by other authors and myself:

1. A new fixed-weight index of nonfarm private hourly earnings adjusted for fringe benefits, including employers' social security tax payments $(w)$.

25. See Paul M. Schwab, "Two Measures of Purchasing Power Contrasted," Monthly Labor Review, Vol. 94 (April 1971), p. 5. Coverage is about 75 percent in manufacturing and about 85 percent in nonmanufacturing industries.

Table 1. Alternative Wage Equations ${ }^{\natural}$

Two-quarter overlapping changes

\begin{tabular}{|c|c|c|c|c|c|c|c|c|}
\hline \multirow[b]{3}{*}{ Equation } & \multirow[b]{3}{*}{ Constant } & & & & & & & ndependent \\
\hline & & \multicolumn{7}{|c|}{ Labor market variables } \\
\hline & & $\begin{array}{l}\text { Total em- } \\
\text { ployment } \\
\text { rate of } \\
\text { manhours } \\
1-U^{L}\end{array}$ & $\begin{array}{c}\text { Inverse of } \\
\text { official } \\
\text { unemploy- } \\
\text { ment rate } \\
1 / U\end{array}$ & $\begin{array}{c}\text { Inverse of } \\
\text { weighted } \\
\text { unemploy- } \\
\text { ment rate } \\
1 / U^{*}\end{array}$ & $\begin{array}{c}\text { Unemploy- } \\
\text { ment } \\
\text { dispersion } \\
D U\end{array}$ & $\begin{array}{c}\text { Vacancy } \\
\text { rate } \\
V\end{array}$ & $\begin{array}{c}\text { Disguised } \\
\text { unemploy- } \\
\text { ment rate } \\
U^{D}\end{array}$ & $\begin{array}{c}\text { Unemploy. } \\
\text { ment rate } \\
\text { of hours } \\
U^{H}\end{array}$ \\
\hline (1) & $\begin{array}{l}-0.208 \\
(-6.5)\end{array}$ & $\begin{array}{l}0.228 \\
(6.6)\end{array}$ & $\cdots$ & $\cdots$ & $\cdots$ & $\cdots$ & $\cdots$ & $\cdots$ \\
\hline (2) & $\begin{array}{l}-0.181 \\
(-8.4)\end{array}$ & $\begin{array}{l}0.197 \\
(8.5)\end{array}$ & $\cdots$ & $\cdots$ & $\cdots$ & $\cdots$ & $\cdots$ & $\cdots$ \\
\hline (3) & $\begin{array}{l}0.004 \\
(0.7)\end{array}$ & ... & $\begin{array}{l}0.00023 \\
(1.3)\end{array}$ & $\ldots$ & $\ldots$ & $\ldots$ & $\begin{array}{l}-0.392 \\
(-5.3)\end{array}$ & $\begin{array}{l}-0.205 \\
(-2.1)\end{array}$ \\
\hline (4) & $\begin{array}{l}0.001 \\
(0.3)\end{array}$ & $\ldots$ & $\begin{array}{l}0.00025 \\
(1.3)\end{array}$ & $\cdots$ & $\ldots$ & $\ldots$ & $\begin{array}{l}-0.343 \\
(-4.3)\end{array}$ & $\begin{array}{l}-0.224 \\
(-2.4)\end{array}$ \\
\hline (5) & $\begin{array}{l}0.001 \\
(0.2)\end{array}$ & $\cdots$ & $\begin{array}{l}0.00013 \\
(0.6)\end{array}$ & $\cdots$ & $\cdots$ & $\cdots$ & $\begin{array}{l}-0.222 \\
(-2.6)\end{array}$ & $\begin{array}{l}-0.276 \\
(-2.4)\end{array}$ \\
\hline (6) & $\begin{array}{l}0.003 \\
(0.5)\end{array}$ & $\cdots$ & $\begin{array}{l}0.00003 \\
(0.1)\end{array}$ & $\cdots$ & $\cdots$ & $\cdots$ & $\begin{array}{l}-0.230 \\
(-2.8)\end{array}$ & $\begin{array}{l}-0.275 \\
(-2.5)\end{array}$ \\
\hline (7) & $\begin{array}{l}0.001 \\
(0.2)\end{array}$ & $\cdots$ & $\begin{array}{l}0.00018 \\
(1.0)\end{array}$ & $\ldots$ & $\cdots$ & ... & $\begin{array}{l}-0.274 \\
(-3.8)\end{array}$ & $\begin{array}{l}-0.197 \\
(-2.0)\end{array}$ \\
\hline (8) & $\begin{array}{l}0.001 \\
(0.2)\end{array}$ & $\ldots$ & $\begin{array}{l}0.00016 \\
(0.6)\end{array}$ & $\ldots$ & $\ldots$ & $\begin{array}{l}0.011 \\
(0.1)\end{array}$ & $\begin{array}{l}-0.274 \\
(-3.7)\end{array}$ & $\begin{array}{l}-0.195 \\
(-1.9)\end{array}$ \\
\hline (9) & $\begin{array}{l}0.001 \\
(0.4)\end{array}$ & $\cdots$ & $\cdots$ & $\begin{array}{l}0.00013 \\
(1.1)\end{array}$ & $\cdots$ & $\cdots$ & $\begin{array}{l}-0.274 \\
(-3.8)\end{array}$ & $\begin{array}{l}-0.180 \\
(-1.8)\end{array}$ \\
\hline (10) & $\begin{array}{l}-0.001 \\
(-0.3)\end{array}$ & $\cdots$ & $\cdots$ & $\begin{array}{l}-0.00014 \\
(-0.8)\end{array}$ & $\begin{array}{l}0.031 \\
(2.1)\end{array}$ & $\cdots$ & $\begin{array}{l}-0.257 \\
(-2.8)\end{array}$ & $\begin{array}{l}-0.100 \\
(-1.0)\end{array}$ \\
\hline (11) & $\begin{array}{l}-0.001 \\
(-0.4)\end{array}$ & $\ldots$ & $\ldots$ & ... & $\begin{array}{l}0.018 \\
(2.3)\end{array}$ & $\ldots$ & $\begin{array}{l}-0.278 \\
(-4.3)\end{array}$ & $\begin{array}{l}-0.086 \\
(-1.0)\end{array}$ \\
\hline
\end{tabular}

Source: Author's estimates.

Note: The sample period is 1954:1-1970:4; numbers in parentheses are $t$-statistics.

a. The dependent variable for equation (1) is the change in the ratio of adjusted compensation per manhour (see Robert J. Gordon, "The Recent Acceleration of Inflation and Its Lessons for the Future," Brookings Papers on Eco- 
2. New measures of excess labor demand, which (a) "blow up" a partial series on vacancies into an estimated aggregate vacancy rate, and (b) introduce the unemployment of hours $\left(U^{H}\right)$ and disguised unemployment $\left(U^{D}\right)$ separately into the wage equation.

3. The use of lagged changes in the personal consumption deflator (rather than the consumer price index) to measure the effect of price expectations on wage change, with weights determined from equations for interest rates on instruments of different maturities.

4. The distinction between the product demand effect of prices and the influence of consumer prices on the expectations of workers.

5. The symmetric treatment of direct labor taxes paid by employers $\left(T_{8}\right)$ and employees $\left(T_{e}\right)$ as elements that may be shifted forward in the short run to raise before-tax wage rates and, subsequently, product prices.

The effect of each of these innovations is demonstrated in Table 1, which

\begin{tabular}{|c|c|c|c|c|c|c|c|c|}
\hline \multicolumn{9}{|l|}{ variables } \\
\hline \multicolumn{3}{|c|}{ Price variables } & \multicolumn{3}{|c|}{ Other variables } & & & \\
\hline \multirow{2}{*}{$\begin{array}{l}\text { Change in } \\
\text { expected } \\
\text { consumer } \\
\text { price } \\
\text { index } \\
g_{\mathrm{c}}{ }^{*}\end{array}$} & \multirow{2}{*}{$\begin{array}{c}\text { Change in } \\
\text { expected } \\
\text { personal } \\
\text { consumption } \\
\text { deflator } \\
\boldsymbol{g}_{d^{\bullet}}\end{array}$} & \multirow{2}{*}{$\begin{array}{c}\text { Change in } \\
\text { product } \\
\text { price } \\
\text { variable } \\
g_{p}-g_{d}\end{array}$} & \multirow{2}{*}{$\begin{array}{l}\text { Change in } \\
\text { employers' } \\
\text { social } \\
\text { security } \\
\text { tax rate } \\
g_{\left(1 / 1-T_{\theta}\right)}\end{array}$} & \multirow[b]{2}{*}{$\begin{array}{c}\text { Change in } \\
\text { employees' } \\
\text { tax rate } \\
g_{\left(1 / 1-T_{e}\right)}\end{array}$} & \multirow[b]{2}{*}{$\begin{array}{c}\text { Guidepost } \\
\text { dummy } \\
D_{G}\end{array}$} & \multirow[b]{2}{*}{$\begin{array}{l}\text { Durbin- } \\
\text { Watson }\end{array}$} & \multicolumn{2}{|c|}{ Standard errors } \\
\hline & & & & & & & $\begin{array}{c}\text { Estimated } \\
\text { to } \\
1970: 4\end{array}$ & $\begin{array}{c}\text { Estimated } \\
\text { to } \\
1968: 4\end{array}$ \\
\hline $\begin{array}{l}0.466 \\
(4.8)\end{array}$ & $\cdots$ & $\cdots$ & $\begin{array}{l}0.736 \\
(1.9)\end{array}$ & $\cdots$ & $\cdots$ & 1.11 & 0.00524 & 0.00522 \\
\hline $\begin{array}{l}0.463 \\
(7.0)\end{array}$ & $\cdots$ & $\cdots$ & $\begin{array}{l}0.939 \\
(3.5)\end{array}$ & $\cdots$ & $\cdots$ & 1.01 & 0.00354 & 0.00357 \\
\hline $\begin{array}{c}0.354 \\
(5.1)\end{array}$ & $\cdots$ & $\cdots$ & $\begin{array}{l}1.096 \\
(4.2)\end{array}$ & $\cdots$ & $\cdots$ & 1.20 & 0.00330 & 0.00332 \\
\hline$\cdots$ & $\begin{array}{l}0.577 \\
(4.9)\end{array}$ & $\cdots$ & $\begin{array}{l}1.029 \\
(3.9)\end{array}$ & $\cdots$ & $\cdots$ & 1.19 & 0.00333 & 0.00333 \\
\hline$\cdots$ & $\begin{array}{l}0.857 \\
(5.6)\end{array}$ & $\begin{array}{l}0.725^{\circ} \\
(2.5)\end{array}$ & $\begin{array}{l}0.967 \\
(3.8)\end{array}$ & ... & $\cdots$ & 1.27 & 0.00317 & 0.00326 \\
\hline$\cdots$ & $\begin{array}{l}0.891 \\
(5.9)\end{array}$ & $\begin{array}{l}0.755^{\circ} \\
(2.7)\end{array}$ & $\begin{array}{l}0.704 \\
(2.5)\end{array}$ & $\begin{array}{l}0.141 \\
(2.0)\end{array}$ & $\cdots$ & 1.38 & 0.00310 & 0.00316 \\
\hline$\cdots$ & $\begin{array}{l}0.756 \\
(5.6)\end{array}$ & $\begin{array}{l}0.454^{\circ} \\
(1.7)\end{array}$ & $0.0^{\circ}$ & $\begin{array}{l}0.163 \\
(2.7)\end{array}$ & ... & 1.43 & 0.00271 & 0.00273 \\
\hline$\cdots$ & $\begin{array}{l}0.760 \\
(5.5)\end{array}$ & $\begin{array}{l}0.475^{\circ} \\
(1.6)\end{array}$ & $0.0^{\circ}$ & $\begin{array}{l}0.160 \\
(2.5)\end{array}$ & ... & 1.46 & 0.00274 & 0.00275 \\
\hline$\cdots$ & $\begin{array}{l}0.741 \\
(5.4)\end{array}$ & $\begin{array}{l}0.487^{\circ} \\
(2.3)\end{array}$ & $0.0^{\circ}$ & $\begin{array}{l}0.161 \\
(2.6)\end{array}$ & $\cdots$ & 1.44 & 0.00271 & 0.00272 \\
\hline$\cdots$ & $\begin{array}{l}0.521 \\
(3.0)\end{array}$ & $\begin{array}{l}0.685^{\circ} \\
(2.6)\end{array}$ & $0.0^{\circ}$ & $\begin{array}{l}0.175 \\
(2.8)\end{array}$ & $\begin{array}{l}-0.001 \\
(-0.7)\end{array}$ & 1.53 & 0.00265 & 0.00265 \\
\hline$\cdots$ & $\begin{array}{l}0.600 \\
(4.0)\end{array}$ & $\begin{array}{l}0.596^{\circ} \\
(2.8)\end{array}$ & $0.0^{\circ}$ & $\begin{array}{l}0.169 \\
(3.3)\end{array}$ & $\ldots$ & 1.50 & 0.00261 & 0.00262 \\
\hline
\end{tabular}

nomic Activity (1:1970), pp. 1-41) to potential productivity; in equations (2) through (11), it is the change in the ratio of the new fixed-weight wage series to potential productivity.

b. See discussion in Ibid., p. 16.

c. This coefficient is the sum of a series of distributed lag coefficients. 
lists first, as equation (1), the wage equation from my earlier article and gradually makes the transition to a new "final" wage equation. The sample period is 1954:1 to 1970:4, an interval with a starting date chosen to eliminate the impact of the Korean war period on the results, and with an ending date chosen to make maximum use of recent experience for hypothesis testing. The last column of Table 1 shows standard errors when the equations are refitted with 1969 and 1970 excluded; they are little changed from the standard errors for the equations fitted to the full sample period, indicating that the conclusions drawn from Table 1 are not sensitive to the inclusion of the most recent two years in the sample period. In all equations, the dependent variable is the two-quarter change in standard unit labor cost-the wage rate divided by standard productivity. ${ }^{26}$

Equation (1) in Table 1 uses the same variables as did my article last year: the total employment rate of manhours, $1-U^{L}$; a measure of the expected rate of change of the consumer price index, $g_{\mathrm{c}^{*}}$; and the change in the social security tax rate, $g_{\left(1 /\left(1-T_{s}\right)\right)}{ }^{27}$ Equation (2) shifts to the new wage variable, with very little change in the coefficients but a marked reduction in the standard error of estimate. In the next equation the total unemployment rate is split into its three components: the official rate (which is entered as the unemployment inverse, $1 / U$ ); the rate of disguised unemployment, $U^{D}$; and the unemployment rate of hours, $U^{H}$. The coefficients on $U^{D}$ and $U^{H}$ are more significant statistically than the official unemployment rate, confirming the suggestion made last year that all three forms of unemployment, not just the official unemployment rate alone, must be taken into account in the study of wage determination. The important role of $U^{D}$ and $U^{H}$ shown throughout Table 1 indicates that these variables are serving as useful proxies for other aspects of labor market tightness, such as the total economy-wide vacancy rate, for which no direct measurement is available.

The new price expectations variable, $g_{d^{e}}$, is introduced in equation (4) and differs from that in equation (3) both in the interest rate equation used to derive the weights (see equation (A.5) in Appendix A) and in the use of

26. Equations for one-quarter change were also calculated, with little difference in the results but with marked negative serial correlation in the residuals.

27. The coefficients differ from those in the version published last year because (a) variables are in the form of two-quarter rather than four-quarter changes; (b) the data have been revised; (c) the sample period is different; and (d) the output growth variable is no longer significant due to the adjustment of the dependent variable for changes in industry mix. 
the personal consumption deflator in place of the consumer price index. ${ }^{28}$ There is no appreciable difference between the two equations in their ability to explain the past, but the coefficient on the new price variable is considerably higher, reflecting the slower rate of growth of the PCD than of the CPI in the $1967-70$ period (that is, to make a given numerical contribution to the wage equation, the weights applied to the change in PCD must be larger since the size of the change is smaller). The difference between the growth rate of the NPD and the PCD $\left(g_{p}-g_{d}\right)$ is introduced in equation (5), where the coefficient listed is the sum of eight distributed lag coefficients. ${ }^{29}$ The result is both a substantial improvement in fit and an increase in the size of the coefficient on the price expectation variable, indicating that the omission of the marginal-revenue-product effect biases downward the coefficient on expected inflation in consumer prices. The variable $\left(g_{p}-g_{d}\right)$ plays no role in the inflationary process in the long run, since product prices and consumption prices grow at about the same rate over a period of years. But in the short run, it has a significant effect on the timing of wage increases. ${ }^{30}$

The effect of direct taxes is explored in the next two equations. Equation (6) indicates that in the current period about one-seventh of the impact of a change in the direct tax rate paid by employees, $g_{\left(1 /\left(1-T_{\mathrm{e}}\right)\right)}$, which includes both social security and personal income taxes, is shifted forward to employers, and six-sevenths of the impact is borne by employees. This contrasts with the change in the social security tax paid by employers, $g_{\left(1 /\left(1-T_{s}\right)\right)}$, which is borne almost entirely by employers, as they have only a limited ability to affect it within the quarter of tax change.

To what extent do employers manage in subsequent quarters to shift the burden of the employer tax back to employees by granting smaller wage

28. The weights used for the expectation variable in Table 1 are based on the equation for the Treasury bill rate. Table 2 illustrates that the weights from the equation explaining Treasury bill rates yield a better explanation of wage change than the weights from the equation explaining the three- to five-year bond rate. The weighting pattern, shown in detail in Table A-1, is virtually identical both in shape and in mean lag to the weighting pattern obtained when past values of price change are included directly in the wage equation; see Table 2, equation (19).

29. In order to minimize the problem of simultaneous equation bias that would arise from the effect current wages have on current prices, the current-period coefficient in the distributed lag pattern is constrained to equal zero.

30. The rates of growth of the NPD and PCD between 1956 and 1970 were virtually identical, although the NPD grew somewhat faster before 1956. 
increases than they otherwise would? Sensible estimates of the lagged effect of changes in the employers' tax could not be obtained without placing a priori restrictions on the pattern of lag coefficients. ${ }^{31}$ For the final estimates presented in Table 1, the following restrictions were imposed on the coefficients of $g_{\left(1 /\left(1-T_{s}\right)\right)}$ : (1) The current period coefficient is +1.0 (as suggested by estimates without lags); (2) earlier period coefficients are uniformly negative (since no theory would predict that an increase in the employer's tax would raise before-tax wages further after being fully included in the beforetax wage in the initial period of the tax change); (3) coefficients of earlier periods decline linearly; and (4) the sum of the earlier period coefficients add to no less than -1.0 (since without this constraint, estimates add to larger negative numbers, implying that employers reduce wages by more than the whole amount of the tax). The best-fitting lag structure, subject to these constraints, involves only the current and three earlier quarters; the estimated coefficients, starting with the current quarter, are $+1.0,-0.5$, $-0.33,-0.17$.

In all cases the same lag pattern (with an unconstrained sum of coeffcients) was applied to the change in the employee tax, $g_{\left(1 /\left(1-T_{e}\right)\right)}$; but in all cases the lagged employee tax variable was insignificant and the coefficient using only the current quarter is shown in the table. The result of substituting the constrained lag pattern on employers' taxes in equation (7) is a very substantial drop in the standard error of the wage equation. The coefficient on the current-quarter change in the employee's tax is quite stable throughout the equations shown in Table 1.

31. In an initial attempt to explore this problem, I estimated wage equations in which past values of the change in the employer tax were included in addition to current values, with their impacts estimated in a relatively unconstrained way using the polynomial distributed lag technique. The results were not theoretically sensible. The coefficients indicated that, holding all other variables constant, in the first year after an increase in the employer tax rate the burden was more than shifted back to employees, while in the second and third years, wage increases were higher than would otherwise be expected and the burden was shifted back to employers again. The polynomial distributed lag coefficients summed to -1.5 over the interval between the first and fifth quarters, and between quarters six and fourteen added to +2.5 . This strange pattern of coefficients in all probability reflected a timing sequence in wage negotiations that the other variables in the wage equation could not explain and that was "picked up" by the flexible distributed lag applied to the social security tax. When the current period coefficient was constrained to equal +1.0 and earlier quarters were restricted to take in declining negative weights, the coefficients of the earlier quarters summed to between -1.5 and -2.0 depending 'on the number of lags permitted, implying an implausible degree of backward shifting of the employer tax. 
The final four equations explore the contributions of alternative labor market variables. The vacancy rate $(V)$, developed from partial data on nonagricultural job openings, appears to make no contribution at all, as is demonstrated in equation (8). Neither aggregate unemployment measure-the inverse of the official unemployment rate, $1 / U$, or the inverse of Perry's weighted unemployment rate, $1 / U^{*}$-is significant alongside the partial measures, $U^{D}$ and $U^{H}$, as is evident from equations (3) through (9). Perry's unemployment dispersion variable, however, makes a statistically significant contribution in equations (10) and (11). The drop in the coefficient on the expected price variable between equations (9) and (10) suggests that part of the acceleration of wage increases in 1968-70 that is attributed to the price variable in equation (9) is in fact due to the growing dispersion of unemployment during these years.

Equation (10) implies a less steeply sloped long-run Phillips curve tradeoff between unemployment and inflation than equation (9) and confirms Perry's conclusion that the long-run Phillips curve has shifted to the right in the 1960s. The small and insignificant coefficient on the guidepost dummy in equation (10) confirms the conclusion in my previous article that the Kennedy-Johnson guideposts were ineffective in reducing the rate of wage increase. Equation (10) is unsatisfactory as the "final" wage equation because the coefficient on the weighted unemployment inverse has an incorrect sign and because the guidepost dummy is insignificant. The equation is therefore refitted as equation (11) with the two variables $1 / U^{*}$ and $D_{G}$ excluded.

The "final" wage equation (11) differs from the outcome of previous research in several respects. Most notable is the exclusion of any conventional unemployment concept, either weighted or unweighted. This does not mean that the Phillips curve has disappeared, however, because the $D U, U^{D}$ and $U^{H}$ variables are all highly correlated with official unemployment and are effective proxies for net excess labor demand. But the relationship of these variables to the official unemployment concept has shifted since the late 1950s, since $D U$ was higher and $U^{D}$ was lower in 1970 relative to the official unemployment rate than they had been in previous recessions. While these variables thus help to explain the absence of any noticeable slowdown in wage increases in 1970, this result is not due to the inclusion of 1970 in the sample period of the regressions; the coefficients on $D U$ and $U^{D}$ are virtually identical in regressions fitted to the period ending in 1968:4. Other novel features of equation (11), in comparison with equations devel- 
oped previously by others and myself, are the dynamic pattern of coefficients on changes in employers' social security contributions, the small but significant positive coefficient on direct taxes paid by employees, the significant influence of the demand-price effect, and the relatively high coefficient of 0.6 on the rate of expected inflation. Since this last result has an important role in determining the slope of the long-run Phillips curve, the sensitivity of the estimate to the use of alternative expected price variables was tested.

Table 2 presents alternative versions of equation (11) fitted with eight different variables representing the expected rate of inflation. Equations (12) through (17) in Table 2 are fitted for two alternative price indexes-the personal consumption deflator and the consumer price index-and for three different sets of weights-a simple one-period lag, and distributed lag weights based on the two interest rate equations of Appendix A. Equation (13) in Table 2 is identical to equation (11) in Table 1. For both price indexes the results based on the Treasury bill weights are better than those based on either the simple one-period lag or the weights from the three- to five-year bond equation, but there is no difference at all in goodness of fit between the two price indexes. The results based on the PCD are preferred in this paper, since the closely similar secular rates of growth of the PCD

Table 2. Effect of Alternative Price Expectations Variables on Basic Wage Equation with Dependent Variable $w / q^{\prime}$

Two-quarter overlapping changes

\begin{tabular}{cclcc}
\hline $\begin{array}{c}\text { Equation } \\
\text { number }\end{array}$ & $\begin{array}{c}\text { Price } \\
\text { index }^{\mathrm{a}}\end{array}$ & \multicolumn{1}{c}{ Source of weights ${ }^{\mathrm{b}}$} & $\begin{array}{c}\text { Price } \\
\text { expectation } \\
\text { coefficient }\end{array}$ & $\begin{array}{c}\text { Standard } \\
\text { error }\end{array}$ \\
\hline$(12)$ & PCD & $t-1$ only & 0.378 & 0.00270 \\
$(13)$ & PCD & TB & 0.600 & 0.00261 \\
$(14)$ & PCD & $3-5$ & 0.528 & 0.00271 \\
$(15)$ & CPI & $t-1$ only & 0.258 & 0.00269 \\
$(16)$ & CPI & TB & 0.480 & 0.00258 \\
$(17)$ & CPI & $3-5$ & 0.431 & 0.00270 \\
$(18)^{\circ}$ & CPI & Livingston survey & 0.215 & 0.00274 \\
$(19)$ & PCD & Estimated in wage equation & 0.765 & 0.00258 \\
\hline
\end{tabular}

Source: Author's estimates.

Note: The sample period is 1954:1-1970:4.

a. PCD is the personal consumption deflator; CPI, the consumer price index.

b. TB is the Treasury bill rate; $3-5$, the rate on three- to five-year government bonds. For a description of the Livingston survey, see text.

c. In equation (18), $U^{H}$ took on the wrong sign and was excluded in the version reported on here. 
and the NPD explained in the price equation allow us to feed the NPD directly into the wage equation in forecasting experiments. The CPI increased at a substantially faster rate than either the NPD or PCD during the 1967-70 period and cannot be used without a separate equation to explain deviations between the growth rates of the CPI and NPD.

Equation (18) presents a test of considerable interest. Some critics object that expectations may not be a simple function of a variable's past values, as assumed in this paper, but may be based in part on other, outside information. Fortunately, a set of actual price expectation estimates is available in the results of a survey conducted for the last twenty-five years by J. A. Livingston, formerly the financial editor of the Philadelphia Bulletin. At six-month intervals, Livingston has surveyed a panel of approximately fifty business economists regarding the change in consumer prices (as well as wages, output, and other variables) that they anticipated over the next six and the next twelve months. Livingston has made his data available to me, and the basic wage equation has been estimated with the rate of change in the price level expected by the Livingston panel used as a proxy for the rate of expected inflation. ${ }^{32}$

An examination of the Livingston index indicates that the survey panel has made significant underestimates of the future rate of inflation during several subperiods of the postwar years. Rational workers should formulate wage demands both to take account of inflation expected in the future and to make up for past underestimates of the inflation rate. Hence, the difference between the rate of change of actual prices and expected prices in the most recent period was tested in addition to the rate of change of the Livingston index in the wage equation. This "catch-up" variable was statistically insignificant, however, and has been excluded from equation (18). The coefficient on changes in price expectations is much lower in equation (18) than in the CPI equation based on Treasury bill weights (16), but the

32. For use in the quarterly equations, the change between the price level in the present month and that expected after a six-month interval was interpolated so as to convert the semiannual series into a quarterly series. Because changes were reported, for example, between the actual November figure and the anticipated June figure, anticipated annual rates of change over the seven-month interval were computed by multiplying the expected change by $12 / 7$. On the hypothesis that the one-quarter rate of change in the wage rate is a function of the rate of change of prices expected now for the following six months, a two-quarter moving average of the annualized Livingston series was the variable entered into equation (18) in Table 2. 
statistical fit is worse, perhaps suggesting that the estimate of price expectations reflected in financial markets is a more accurate reflection of worker sentiments than the estimate by a panel of business economists.

In the final equation in Table 2, the lags on expected price changes are estimated in the wage equation itself rather than from an interest rate equation. The distributed lag weights are subject to the same constraints as those in the interest rate equation used to obtain the expected price variable for the other wage equations. Equation (19) is virtually identical to equation (13) in goodness of fit, in the shape of the lag distribution, and in the mean lag of the lag pattern (4.1 quarters as compared with 4.4 quarters in the Treasury bill equation described in Appendix Table A-1). The major difference is that the sum of the coefficients in equation (19) is somewhat larger than that in equation (13). The similarity of equations (19) and (13) offers indirect evidence that the price expectations of workers over the near term are similar to those reflected in financial markets. Equation (13)-that is, equation (11) of Table 1-rather than (19) is the choice for simulation and forecasting experiments because it is less likely to contain biased coefficient estimates.

The coefficient on the expected price level in my basic wage equation is 0.600 . How confident can we be that this value is significantly different from unity, and thus that the long-run Phillips curve has a negative slope? Table 3 shows the sum of squared residuals for the final wage equation when the coefficient on the expected rate of inflation is constrained at different values between 0.1 and 1.2. A 5 percent confidence interval stretches between coefficient values of 0.3 and 0.9 . Because of the wide range of parameter values within the 5 percent confidence interval, the estimate of 0.6 in the final wage equation cannot be regarded as precise, but it is significantly different from unity at the 1 percent level. ${ }^{33}$

\section{The Determination of Prices}

Once the wage is determined by one of the final wage equations, the basic pace of the inflationary process is bounded within a fairly narrow region.

33. The statement is based on an $\mathcal{F}$ test carried out according to the procedure recommended in Franklin M. Fisher, "Tests of Equality between Sets of Coefficients in Two Linear Regressions: An Expository Note," Econometrica, Vol. 38 (March 1970), p. 363. 
Table 3. Sensitivity of Errors in Basic Wage Equation to Alternative Constraints on Coefficient of Price Expectations Variable

\begin{tabular}{cc}
\hline Coefficient & $\begin{array}{c}\text { Sum of squared } \\
\text { residuals }\end{array}$ \\
\hline 0.1 & 0.000476 \\
0.2 & 0.000449 \\
0.3 & 0.000428 \\
0.4 & 0.000413 \\
0.5 & 0.000404 \\
0.6 & 0.000401 \\
0.7 & 0.000404 \\
0.8 & 0.000413 \\
0.9 & 0.000428 \\
1.0 & 0.000449 \\
1.1 & 0.000476 \\
1.2 & 0.000509 \\
\hline
\end{tabular}

Source: Author's estimates.

The price equation in this paper tests the hypothesis that in the long run the relative shares of labor and nonlabor income are constant. ${ }^{34}$ An equivalent statement is that in the long run the price level is "marked up" by a fixed fraction over "standard" unit labor cost $(w / q$ '), estimated as the wage rate $(w)$ divided by an estimate of productivity at a "standard" level of capacity utilization $\left(q^{\prime}\right)$. In the short run, however, the price equation introduces four basic hypotheses to explain fluctuations in the ratio of price to standard unit labor cost.

1. Excess demand for commodities. The mark-up fraction is postulated to depend on the excess demand for commodities. ${ }^{35}$ Firms are relatively uninhibited in raising prices when they are straining to produce output during periods of a high backlog of unfilled orders relative to their capacity to produce. They become more cautious about raising prices in the later stages of a business expansion, after they have worked off their order backlog. The crucial role of order backlogs is introduced into the price equation by

34. For evidence from cross-section data that the elasticity of substitution between labor and capital is unity in U.S. manufacturing, see Paul Zarembka, "On the Empirical Relevance of the CES Production Function," Review of Economics and Statistics, Vol. 52 (February 1970), pp. 47-53.

35. Since the level of excess demand enters multiplicatively with the level of labor cost in determining the price level, the rate of growth of excess demand enters additively with the growth of labor cost in determining the rate of growth of the price level. 
allowing the mark-up fraction to vary as a function of the ratio of unfilled orders to capacity $(U F / K) \cdot{ }^{36}$

2. Lags. Even if the level of excess demand is constant, the ratio of price to standard unit labor cost may fluctuate in the short run if the response of price to a change in the wage rate occurs with a lag. In this case a sudden increase in the growth rate of wages will temporarily raise unit labor costs until sufficient time has passed for prices to catch up. To estimate the length of this lag, the price equation fits a series of distributed lag coefficients to current and past changes in standard unit labor cost $\left(w / q^{\prime}\right)$.

3. Productivity deviations. In this paper the level of productivity at a "standard" level of capacity utilization $\left(q^{\prime}\right)$ is assumed to lie along a trend line passing through cyclical peaks in productivity. Estimates made by price setters of standard productivity may diverge from this trend line for a substantial period. If price setters pay some attention to deviations of actual productivity from trend, but do not base price decisions exclusively on actual productivity, prices will respond to changes in the ratio of actual to trend productivity $\left(q / q^{\prime}\right)$. This variable, like the wage rate $(w)$, is assumed to influence price decisions with a lag, since price setters may wait several quarters to see if a shortfall in productivity continues before raising prices.

4. Other compensation. The wage index explained in the wage equation excludes many forms of compensation that are part of total labor costs. To the extent that the price level is set in relation to total compensation rather than solely to the wages and salaries of production and nonsupervisory workers, the rate of change of prices should depend on the rate of change in the ratio of total compensation per manhour to the wage index $(C M H / w)$. If broader coverage were the only difference between the series, a coefficient of unity on this ratio would mean that price setters adjust completely for changes in these other forms of compensation. But the fitted coefficient might be less than unity to the extent that a portion of changes

36. This measure was first suggested by George deMenil, "Vintage Production Functions, Monopolistic Competition, and Price Determination" (unpublished manuscript, July 30,1969). Following deMenil, the ratio of unfilled orders to capacity used here is "detrended," that is, computed as the ratio of actual $U F / K$ to a trend line extended between peaks in 1952:3,1956:3, and 1966:4. The $U F / K$ measure is used here in preference to the ratio of new orders to shipments, the excess demand variable in my previous paper, because the latter reaches its peak about a year before the former in most business expansions and has little correlation with price behavior after 1951. The choice of $U F / K$ makes sense if firms regard fluctuations in new orders as transitory unless the integral of new orders is substantial enough to raise unfilled orders relative to capacity. 
in $C M H / w$ reflects changes in industry mix or errors of measurement. The effect of this variable is largely cyclical, since the ratio of compensation per manhour to the wage index has a secular increase of only 0.2 percent per annum in the 1954-70 period.

Beyond these four hypotheses, other variables might have been included. Since output in the nonfarm private economy is produced with capital and materials as well as with labor, the unit costs of these other inputs should have an influence on price. But additional explanatory variables require additional equations in turn to explain them, introducing an undesirable degree of complication into a wage-price model that is designed to be simple and easily manipulated. In place of explicit treatment of other costs, I rely on the assumption of constant income shares to tie the price level in the long run to unit labor cost. Given constant shares, a doubling of unit labor cost must cause the price level to double; unit capital cost must also double, an event that will occur through some combination of an increase in the price of capital services and the accumulation of added capital per unit of output. Thus the estimate of the elasticity of the price level to changes in standard unit labor cost should be expected a priori to be unity if the assumption of constant shares is valid.

The final fitted price equation is:

$$
\begin{aligned}
& g_{p_{t}}=0.0002+0.601 g_{(C M H / w)_{t}}+0.024 g_{(U F / K)_{t}}+1.060 g_{\left(w / q^{\prime}\right)_{L}} \\
& \text { (0.2) (3.3) } \\
& -0.243 g_{\left(q / q^{\prime}\right)_{L}} \\
& (-2.0) \\
& \bar{R}^{3}=0.742 \text {, Durbin-Watson statistic }=2.21, \\
& \text { standard error }=0.00214 \text {. }
\end{aligned}
$$

The sample period is 1954:2-1970:4, all variables are in the form of onequarter changes, and the subscript $L$ indicates that the coefficient shown is the sum of a series of distributed lag coefficients estimated as described in Appendix $\mathrm{A} ;{ }^{37}$ the numbers in parentheses are $t$-statistics.

The sum of the coefficients on standard unit labor cost, $w / q^{\prime}$, is slightly greater than the a priori value of unity, but this does not imply that in the long run there will necessarily be a reduction in labor's share of income, because the elasticity of price to a change in the ratio of $C M H$ to $w$ is significantly less than unity. Thus the ratio of $C M H$ to price-that is, labor's

37. To limit the number of parameters estimated, a lag in the effect of $g_{(\mathrm{CMH} / w)_{t}}$ was allowed by including it in the form of a four-quarter change at a quarterly rate. 
share-can remain constant even with a 1.06 elasticity of price to changes in $w / q^{\prime}$ if $C M H / w$ increases fast enough. For instance, the parameter values imply that labor's share will remain constant at rates of growth of 3.0 percent per annum for $w / q^{\prime}$ and of 0.4 percent for $C M H / w$, in which case both price and $C M H$ would grow at 3.4 percent per annum.

The distributed lag coefficients indicate that about two-thirds of the ultimate effect of a change in wages on the price level occurs within the first year. About two-thirds of the ultimate effect of a change in $q / q^{\prime}$ also occurs during the first year. Increases in actual productivity cause price setters to raise their estimate of standard productivity, which in turn reduces their estimate of standard unit labor cost and hence the price they decide to set, given the values of other variables. The increase in the ratio of unfilled orders to capacity was constrained to affect the price level immediately, after experiments suggested that lags are short.

Taken together, the fitted coefficients in the price equation suggest a cyclical pattern in which the dominant inflationary force in the early stages of a business expansion is an increase in the ratio of unfilled orders to capacity, somewhat moderated by above-average increases in productivity. Then, as the backlog of unfilled orders is run down and the inflationary pressure from this source subsides, prices are pushed up by a reduction in productivity growth and the effect of wage increases. The equation implies that profits, which depend on the ratio of the price level to actual unit labor cost, rise rapidly in the beginning of an expansion when excess demand pushes up price while unit labor cost growth is moderated by rapid productivity advance. But subsequently there is a period of profit squeeze as the declining pressures of demand are reffected in moderated price increases while a slowdown in productivity growth boosts unit labor costs.

\section{Simulations and Predictions}

THE EXPLANATION OF WAGE AND PRICE BEHAVIOR, 1964-70

The wage rate. In the left frame of Figure 2, the actual four-quarter change in the fixed-weight index of standard unit labor cost is compared with predicted values from equation (11) of Table 1. The equation is able accurately to trace the acceleration in the rate of increase in the wage rate between late 1964 and early 1966, the slower rate of increase in 1966, the rapid acceleration between early 1967 and early 1969, and the leveling off in 
1969-70. The major errors lie in a tendency to overpredict in late 1966 and 1967 and to underpredict in 1968 . Unlike the equations developed last year, there is no tendency to underpredict wages during 1970. In fact, the deceleration in wage increases predicted for 1970 (from 4.29 percent in the four quarters ending in 1969:4 to 4.23 percent in the four quarters ending in 1970:4) is less than the actual deceleration from 4.20 to 3.95 percent.

The right frames of Figure 2 decompose the fitted value from the wage equation into the separate contributions of each variable. The separate contributions, when added vertically, equal the fitted value in the left frame. The contribution of price expectations was gradually to push upward the rate of increase of wages. This variable explains why the increase in wages did not slow down markedly in the 1970 recession, since the growth of the expected price level was more rapid in 1970 than in any earlier year. The other variables explain why the acceleration of the rate of increase in wages between 1964 and 1969 was irregular and did not follow the smooth path of the price expectations variable.

The middle frame on the right shows the contribution of the unemployment dispersion variable in pushing up the rate of increase of predicted wages in 1964-66 and again in 1968-69. That frame also illustrates the substantial role of disguised unemployment, which pushed up the rate of wage inflation throughout the period and also moderated the decline of wage increases in 1970 . The contributions of hours unemployment and the product-demand-price effect were very small during this period. The top frame on the right illustrates the impact of changes in tax rates on the timing of wage changes. The increase in social security taxes paid by employers had a positive influence on the wage rate in 1966 and an offsetting negative effect in 1967. The major impact of changes in the employee tax rate was negative after the 1964 cut in the personal income tax rate, and positive both after the 1966 boost in social security taxes and again in late 1968 and early 1969 after the introduction of the tax surcharge in July 1968. The gradual reduction in the surcharge moderated wage increases in late 1969 and throughout 1970. In simulations reported in the concluding section, I calculate the net inflationary effect of both employers' and employees' taxes when the wage and price equations interact.

The price level. The four-quarter rate of inflation predicted by the price equation when actual wage changes are used in predicting prices is shown as the dashed line in the left frame of Figure 3; there these predicted values are compared with the actual values, illustrated by a solid line. The price 
Figure 2. Actual and Predicted Changes in Standard Unit Labor Cost, and the Contribution of Each Determinant, 1964-70

Percentage points

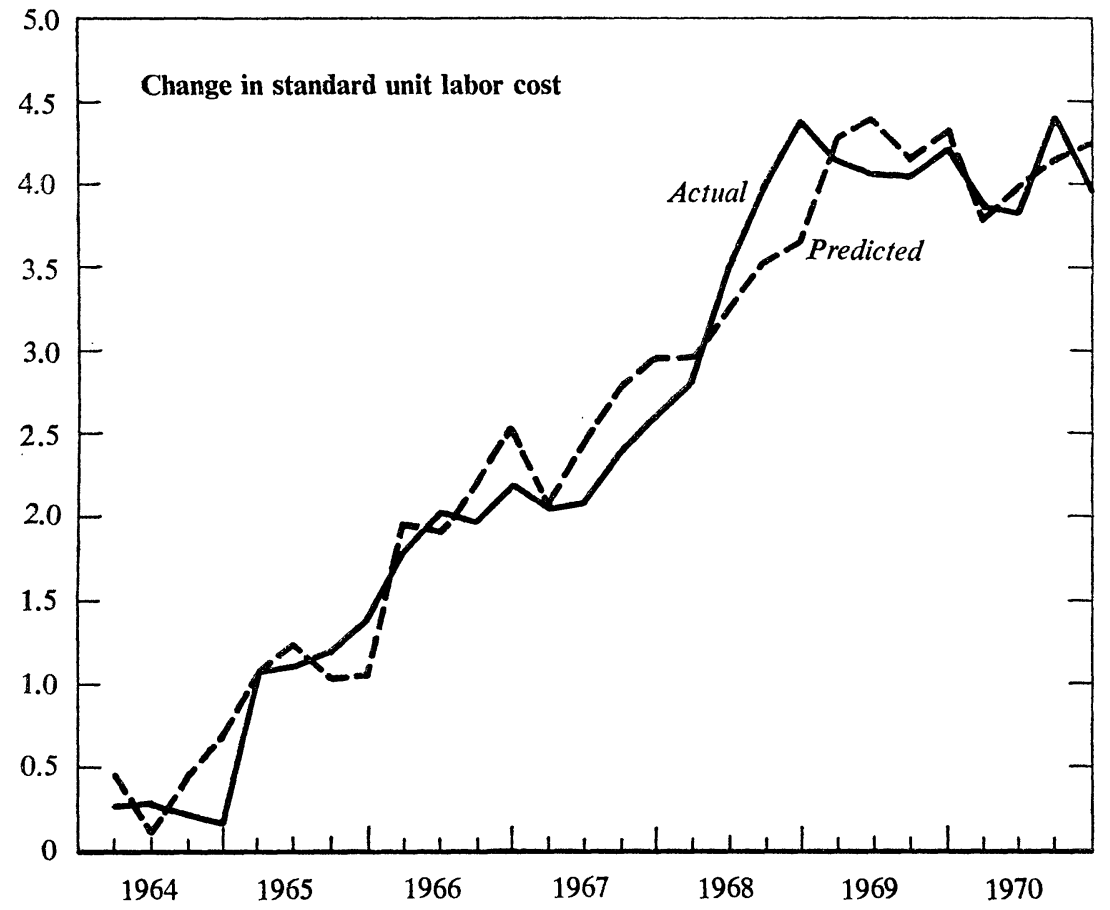

equation tracks the actual experience very closely during the 1964-70 period, with a particularly accurate set of fitted values between 1964:1 and $1968: 2$. The period 1968:3-1970:1 is characterized by an overprediction of the inflation rate by an average annual rate of 0.34 percent; the only substantial underprediction is in the last quarter of 1970 . The equation accurately traces the temporary increase in the rate of inflation in late 1964, the decline in late 1965, the rapid acceleration during 1966, the plateau of 1967, and a second phase of acceleration between early 1968 and mid-1969. Unlike that estimated last year, the equation has no tendency to predict a decline in the rate of inflation in 1970, and in fact predicts an inflation rate in the four quarters ending in 1970:4 (4.70 percent) higher than that predicted for the four quarters ending in 1969:4 (4.55 percent).

The right portion of Figure 3 illustrates the contributions of the four in- 
Figure 2 (continued)

Contribution of determinants to predicted change

Percentage points
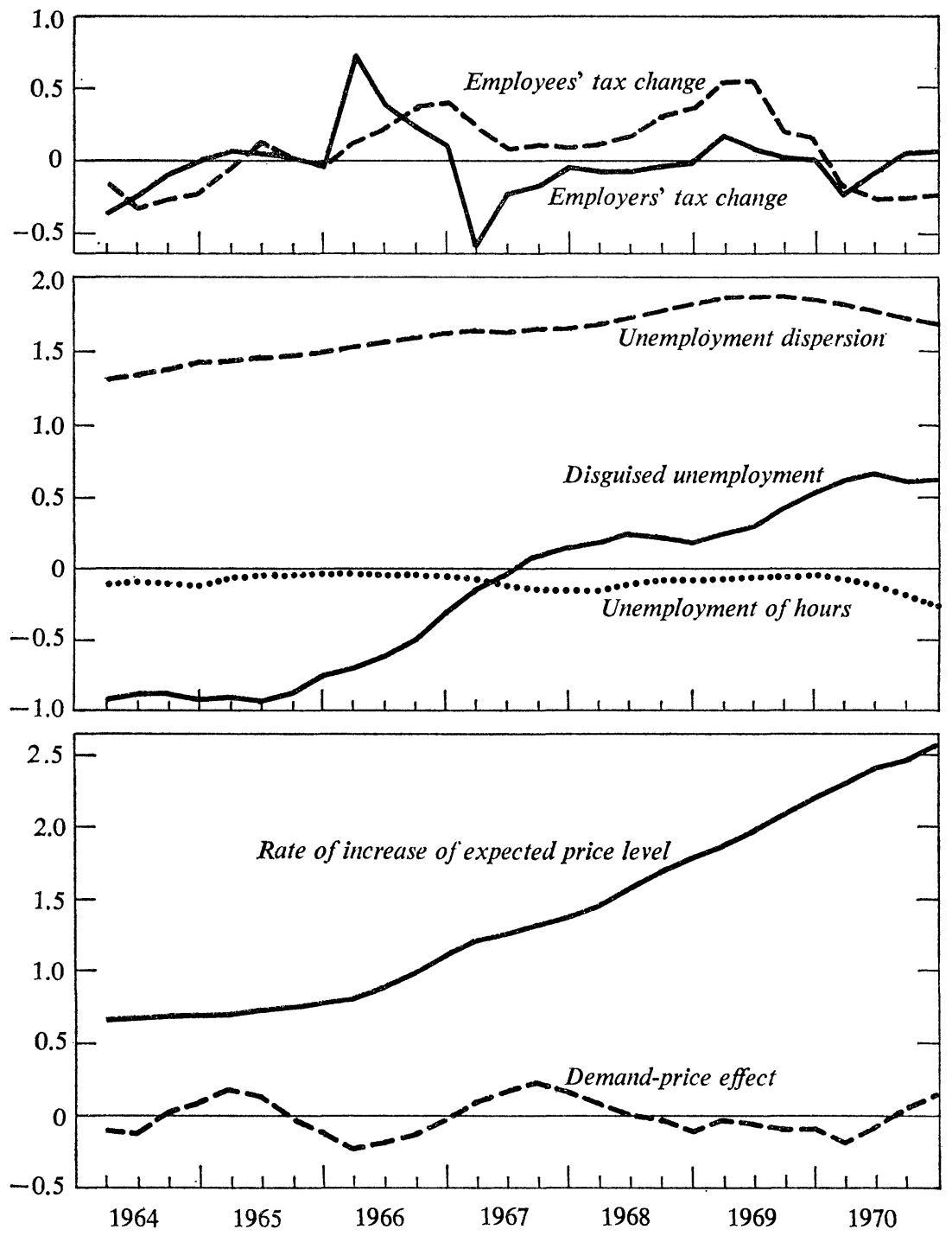

Sources: Actual-Survey of Current Business, various issues; predicted-author's estimates, see text. Note: Changes are over four-quarter intervals. 
Figure 3. Actual and Predicted Changes in Price Level, and Contribution of Each Determinant, 1964-70

Percentage points

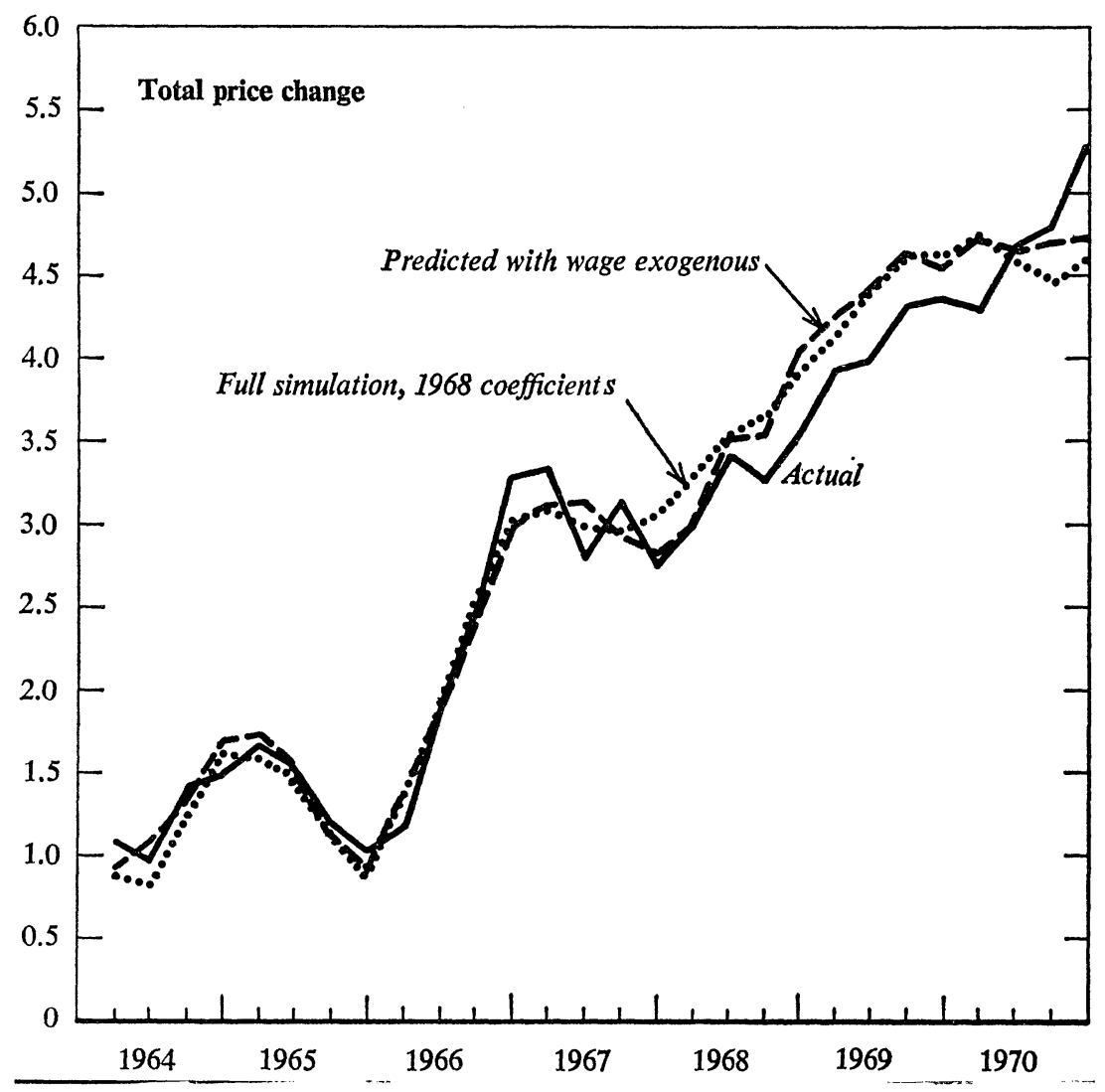

dependent variables to the rate of inflation predicted by the price equation. Increases in standard unit labor cost were the dominant force during most of the period. But productivity deviations played a role in restraining inflation during the early stages of the business expansion in 1964-66 and in aggravating the inflation during 1969-70. And both the ratio of unfilled orders to capacity and the ratio of compensation to wages pushed up the price level in 1964-65 before there was any increase in standard unit labor cost. In a parallel fashion, both variables contributed to the prediction of a reduction in price inflation relative to the increase in labor cost during 1970. The dashed line in the left frame of Figure 3 is not a prediction of the 
Figure 3 (continued)

\section{Contribution of determinants to predicted change}

Percentage points
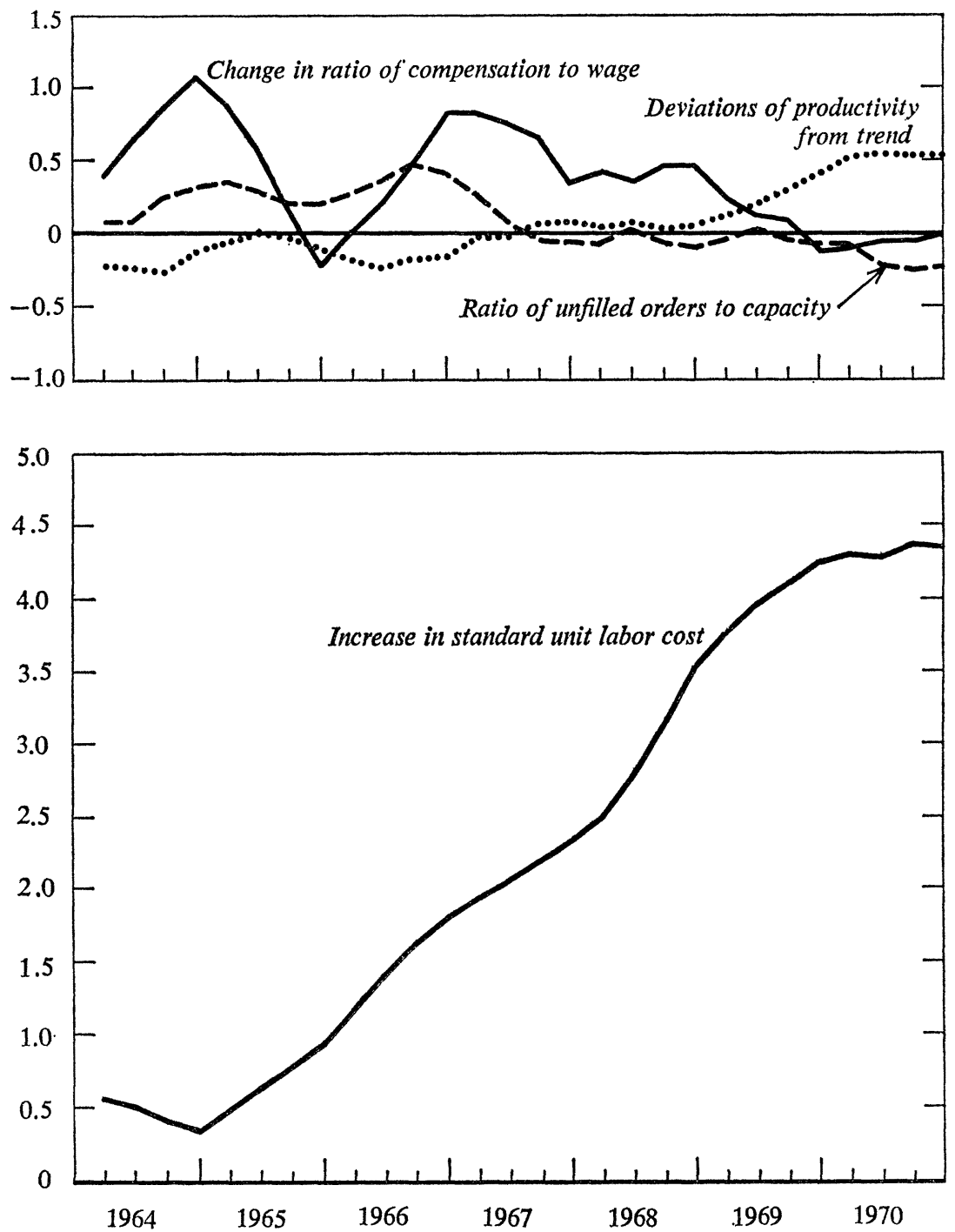

Sources: Actual-Survey of Current Business, various issues; predicted-author's estimates, see text. 
complete wage-price model, but only of the price equation itself when the wage rate is held exogenous. How well does the model track when the wage and price equations are allowed to interact? For the complete model simulation of the 1964-70 period, the wage and price equations employed are fitted only through 1968, in order to illustrate the predictions that the model would have made at the end of 1968 if accurate predictions of the exogenous variables had been available. Employing only information on the history of prices through 1963:4, and the values of all exogenous variables in the wage and price equations, but generating its own estimates of wages and expected prices, the wage-price model is able to track the path of actual inflation during the 1964-70 period with considerable accuracy, as shown by the dotted line in the left frame of Figure 3. While the complete model overpredicts inflation by a moderate amount between 1968:3 and 1970:1, little decline is predicted in the rate of inflation in 1970. The predicted rate of inflation in the four quarters ending in 1970:4 is 4.57 percent, almost the same as the 4.59 percent rate in the four quarters ending in 1969:4. ${ }^{38}$ The extension of the sample period to 1970 causes very little change in the coefficients on the independent variables in the wage and price equations. A complete model simulation for 1964-70, using the equations fitted to the longer sample period, produces predicted values virtually identical to the curve in Figure 3 labeled, "full simulation, 1968 coefficients."

\section{TRADEOFFS BETWEEN UNEMPLOYMENT AND INFLATION}

The estimated wage and price equations can be combined to calculate the long-run tradeoff between inflation and unemployment. In this calculation no role is played by variations in the ratio of actual to standard productivity, the ratio of unfilled orders to capacity, or the ratio of product to consumption prices, all of which are assumed to be constant in the long run if the unemployment rate stays constant. It is assumed that all tax rates remain constant and that the ratio of total compensation per manhour to the wage rate of production workers increases at its secular postwar rate of 0.2 percent per year. With these assumptions the wage equation is substituted into the price equation, and when the rate of expected inflation is set equal to the actual rate of inflation (since by definition in long-run equilibrium the actual and expected rates of inflation are equal), then

38. The errors in the dynamic simulation do not cumulate. The predicted level of the price index in 1970:4 is 1.3142, compared with an actual value of 1.3155 . 


$$
g_{p}=-0.0020+0.0965 D U-1.48 U^{D}-0.455 U^{H} .
$$

All coefficients have been adjusted to apply to annual rates of inflation. While this long-run price equation cannot be plotted on a single diagram as it stands, the equations of Appendix B can be used to calculate the values of the labor market variables in equation (21) that would accompany any given level of the official unemployment rate; hence the inflation rate that would be associated with this given official unemployment rate can be calculated. ${ }^{39}$

The result is the long-run tradeoff curve drawn as a solid line in Figure 4. The curve is somewhat steeper than that derived in my article last year and is slightly curved, due to the nonlinear relationship of total and official unemployment shown in Appendix B. In the interval between 2.6 and 3.7 percent unemployment, a 1 percentage point change in the unemployment rate is associated with a 2.4 percentage point change in the rate of inflation; in the 3.7 to 4.9 percent unemployment interval, with a 1.7 percentage point change in inflation; in the 4.9 to 6.3 interval, with a 1.4 percentage point change in inflation; and in the 6.3 to 7.8 percent interval, with a 1.3 percentage point change in inflation. The slope of the curve below 3.5 percent unemployment or above 6 percent unemployment is not firmly based on the historical data, of course, since the unemployment rate remained within those bounds for all but brief intervals during the sample period. ${ }^{40}$

The wage-price model supports Perry's finding that the Phillips curve shifted to the right between the mid-1950s and late 1960s. The long-run Phillips curve depicted in Figure 4 would be in a more favorable position with the unemployment dispersion of the mid-1950s. To achieve a steady long-run inflation rate of 3.0 percent with today's unemployment dispersion requires an unemployment rate of 5.2 percent, whereas this inflation rate

39. The equations shown in Appendix B can calculate only the sum of $U^{D}$ and $U^{H}$ associated with various levels of official unemployment, not the breakdown of this sum between $U^{D}$ and $U^{H}$, and so the average of the coefficients on $U^{D}$ and $U^{H}$ in equation (21) is applied to this estimate of $U^{D}+U^{H}$.

40. The discussion of wage determination above indicated that a fairly wide range of price expectation coefficients in the wage equation is consistent with the historical data Table 3 reports the calculation of a version of the final wage equation in which the price expectation coefficient was constrained to be 1.0. Although the significance test of that table still gives a value of 1.0 less than a 1 percent probability, this equation can be substituted into the price equation to determine the "natural" unemployment rate below which inflation would continuously accelerate. With the unemployment dispersion that characterizes the United States in the early 1970 s, the computation yields a "natural" unemployment rate of 5.5 percent. 
Figure 4. Long-Run and Short-Run Tradeoffs between Unemployment and Inflation

Inflation rate, percent per year

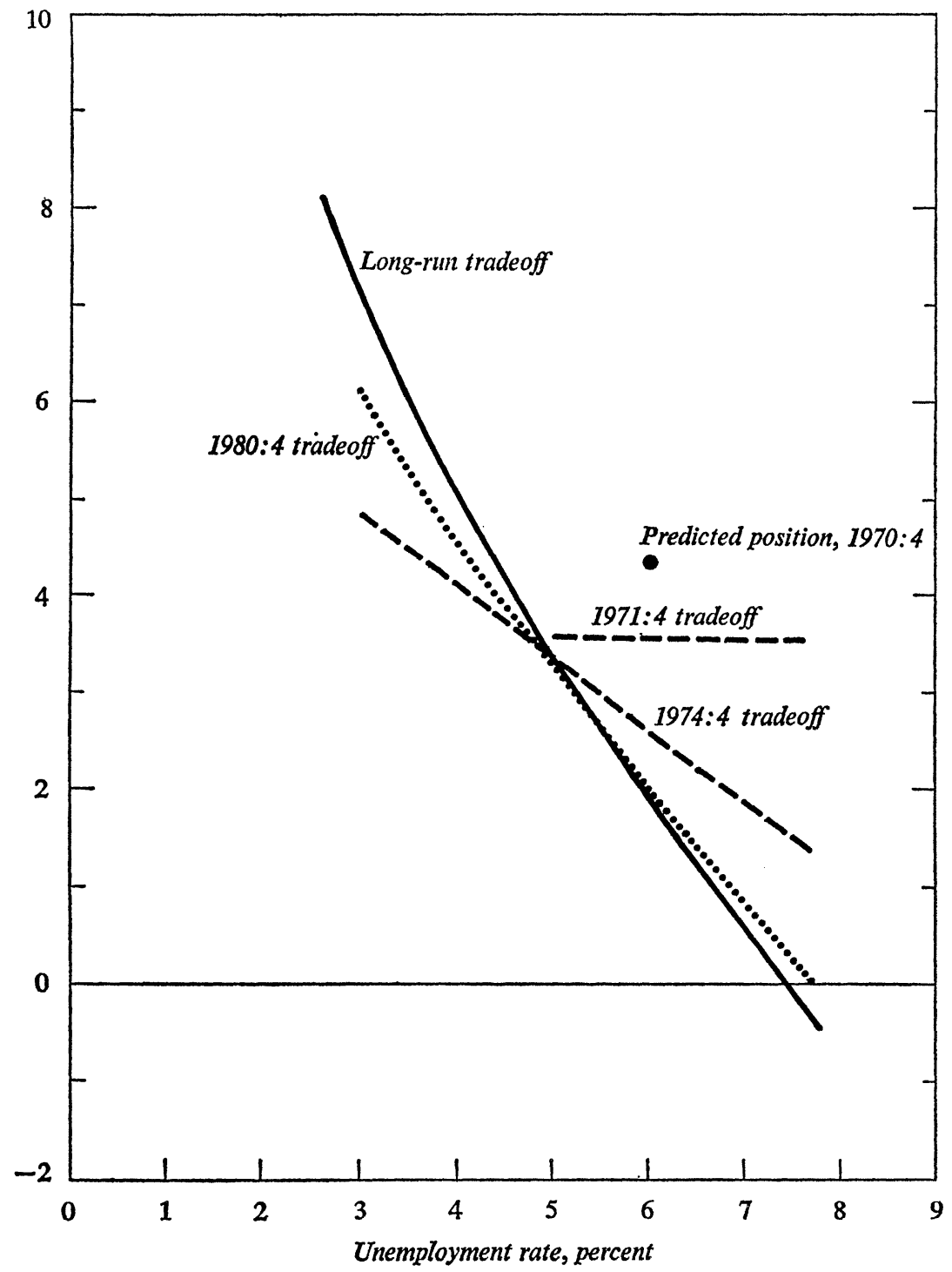

Source: Author's estimates; see text. 
was consistent with a 4.1 percent unemployment rate with the dispersion of 1956. Or, putting it another way, the actual average 1956 unemployment rate of 4.1 percent is associated with a long-run inflation rate of 3.0 percent with the 1956 level of unemployment dispersion, but with a 4.9 percent long-run rate of inflation with the level of dispersion that (according to equation (B.10) in Appendix B) would accompany an official unemployment rate of 4.1 percent during the next several years. ${ }^{41}$

In the short run, the change in the inflation rate resulting from a change in the unemployment rate is much smaller than is suggested by the long-run tradeoff curve. From a starting point of 1970:4, short-run tradeoff curves can be calculated for alternative unemployment rates in future years, as shown in Figure 4. ${ }^{42}$ First, beginning in 1971:1, several simulations were calculated with different rates of output growth chosen to yield (by means of the equations of Appendix B) rates of unemployment ranging between 5.0 and 7.6 percent in 1971:4. The inflation rate in 1971:4 that the full wage-price model predicts would accompany each of these unemployment rates is plotted in Figure 4 as the line marked "1971:4 tradeoff." This shows that from the starting position of 1970:4 any unemployment rate in $1971: 4$ between 5.0 and 7.6 percent would be accompanied by virtually the same inflation rate-about 3.6 percent.

If the same experiment is carried out for a somewhat longer period, the inflation-unemployment tradeoff line becomes steeper and begins to approach the long-run tradeoff curve. From the same starting point of 1970:4, simulations were calculated with different rates of output growth chosen to yield rates of unemployment ranging between 3.0 and 7.6 percent in 1974:4. The line marked "1974:4 tradeoff" indicates that, beginning in $1970: 4$, the choice by policy makers of a path of output growth rapid enough to reach 3.0 percent unemployment by $1974: 4$ would cause an inflation rate in that quarter of 4.9 percent as compared with a slower rate of 2.5 percent at that time if output growth were restricted to the slower path needed to keep the unemployment rate constant at 6.0 percent. Fi-

41. The wage equation with a unitary coefficient on price expectations yields a 5.1 percent "natural" rate of unemployment with 1956 dispersion, as opposed to the 5.5 percent rate with 1970 dispersion. The rightward shift in the Phillips curve referred to in the text is similar in magnitude to that calculated by Perry, "Changing Labor Markets."

42. The "starting point" of 1970:4 assumes the actual rate of employment, but the rate of inflation is that predicted by the wage-price model in a simulation that begins in 1969:4. All the simulations reported on in this section are continuations, along different outlook and unemployment paths, of this initial five-quarter simulation. 
nally, each of these simulations was continued after 1974:4 with an output growth rate chosen to keep the unemployment rate constant at the level reached in 1974:4. The "1980:4 tradeoff" line shows that a given difference in the unemployment rate between the simulations is associated with a growing differential in the inflation rate over the period between 1974 and 1980. But even by 1980:4, ten years after the initial divergence of the output paths in the various simulations, the tradeoff curve has not yet reached its long-run position.

\section{FORECASTS FOR ALTERNATIVE PATHS}

\section{OF ECONOMIC RECOVERY}

Forecasts of the future behavior of prices can be calculated from the estimated wage and price equations when the model of Appendix B is used to generate forecasts of all explanatory variables, a process that requires information only on the projected path of growth of real output. Alternative forecasts are illustrated in Figure 5 for two paths of recovery from the economic situation of 1970:4.

Path $A$ traces rapid recovery to a 3.9 percent unemployment rate by the end of 1972, which requires a 7.5 percent annual rate of output growth between 1970:4 and 1972:4, followed thereafter by growth at the 4.3 percent assumed rate of growth of potential output.

Path $B$ is a more cautious route to full employment. Output grows at the potential rate of 4.3 percent until the end of 1972, followed by three years of 6.4 percent annual output growth until the end of 1975 .

The two paths generate different rates of inflation during the recovery to full employment, since the long period of high unemployment along path $\mathrm{B}$ leads to a reduction in the expected rate of inflation, which in turn moderates the wage demands that accompany any given unemployment rate as the economy returns to full employment. But eventually, after the economy settles down at a 3.8 percent unemployment rate, the inflation rate of path $B$ begins to approach that of path A. These simulations were not continued long enough to determine the exact year in which the inflation rates of the two paths converge, but by 1980:4 the inflation rate along path $B$ is only 0.3 percentage point lower than that along path $A$ (at an annual rate).

The simulations confirm the conclusion of last year's article that policy makers cannot "buy" permanent price stability and full employment (when 


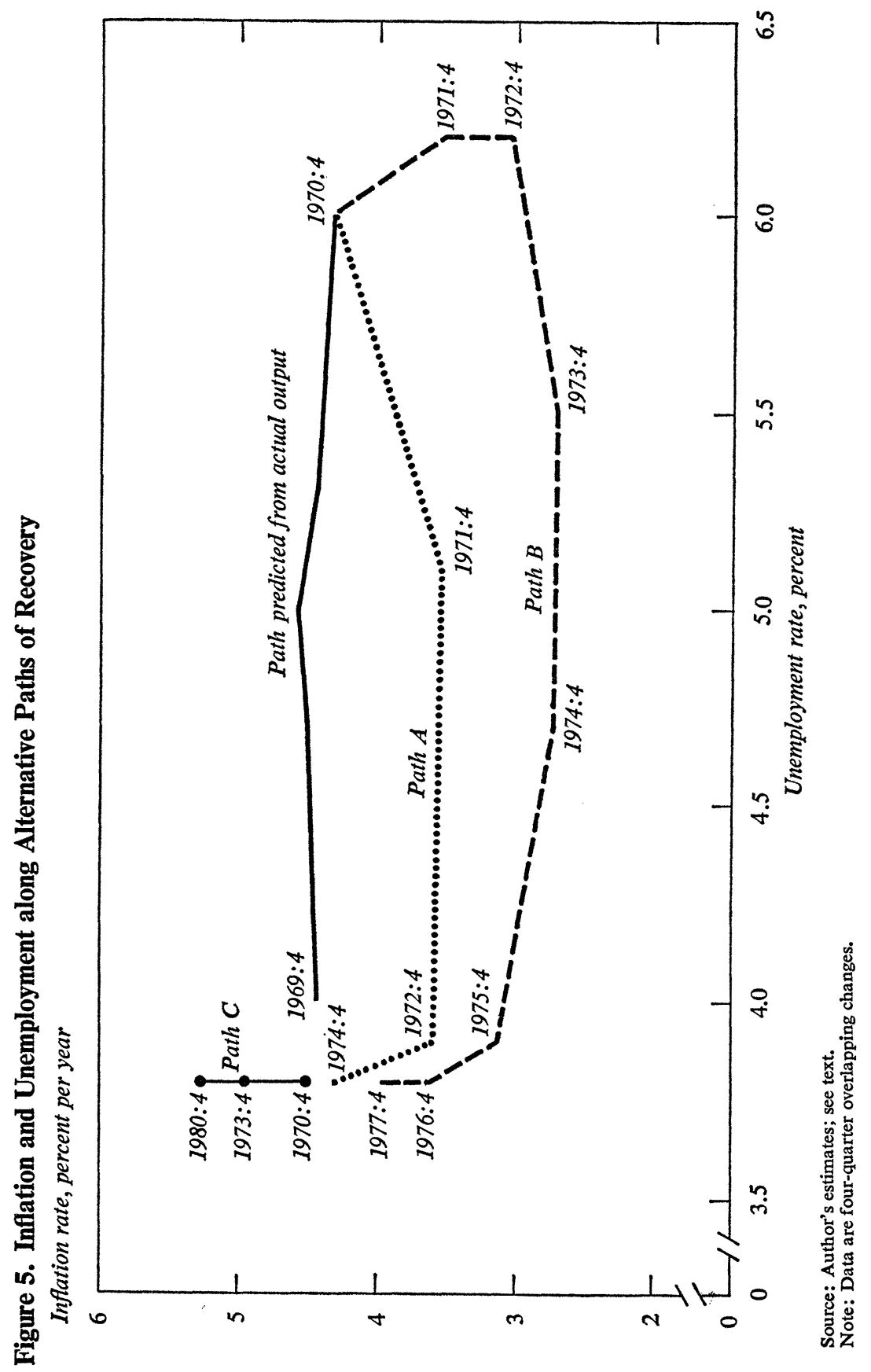


defined as a 3.8 percent unemployment rate) by engineering a recession. The difference in this year's simulations is that the longer lags in the new wage and price equations lengthen the period before the rates of inflation along alternative paths of recovery converge to the same value. Along path B the economy receives a sort of payoff for suffering in 1970-74 in the form of a lower rate of inflation between 1975 and 1980. But the advantage of lower inflation along path $B$ is achieved only at the cost of $\$ 171$ billion in forgone output at today's prices! Because the current rate of inflation is heavily dominated by past events that have determined expectations, and because the forecasts begin with considerable slack in the economy, monetary and fiscal policy makers can push the unemployment rate to the level they consider optimal in the long run without risking a renewed acceleration of inflation. When the assumed paths of output growth are combined with the inflation predictions, the model enables us to calculate that an 11.1 percent growth rate of nominal income would be necessary between 1970:4 and 1972:4 to achieve path A, requiring a 1971 gross national product of $\$ 1,060$ billion. Path B involves more moderate rates of nominal income growth in the five years to $1975: 4$ of, respectively, 7.9, 7.3, 9.1, 9.2, and 9.5 percent.

The negligible permanent impact on the inflation rate and huge output loss associated with the choice of path B instead of path A suggests another comparison, based on this question: What benefits have been derived from the recession of 1970 , as opposed to an alternative policy that would have maintained continuous full employment? Path $\mathrm{C}$ assumes continuous and steady growth of output at the 4.3 percent growth rate of potential output beginning in 1969:4, resulting in a permanent unemployment rate of 3.8 percent. The predicted rate of inflation during 1971 would average more than 1 percentage point faster along path $\mathrm{C}$ than along path $\mathrm{A}$, but subsequently the advantage of path A would narrow until by 1980:4 the inflation rate along path $\mathrm{C}$ would be only 0.5 percentage point faster than that along $\mathrm{A}$. This small benefit of path $\mathrm{A}$ is purchased at the cost of approximately $\$ 100$ billion in lost output (in today's prices) as compared with path $\mathbf{C}$.

\section{Conclusions}

The statistical investigation carried out in this paper suggests answers to four important questions: 
First, what are the fundamental determinants of inflation? The rate of inflation is increased permanently when labor market tightness increases to a new higher level. The regressions confirm the suggestion made in last year's article that disguised unemployment and the unemployment of hours should be taken into account in measures of labor market tightness, and they support Perry's recent demonstration that the increased dispersion of unemployment in the 1960s shifted the inflation-unemployment tradeoff in an unfavorable direction. The rate of inflation at any given time also depends crucially on the expected rate of inflation inherited from the past. Factors that contribute to temporary increases in the rate of inflation are increases in social security or personal income tax rates, a sudden acceleration of the demand for commodities (which raises the ratio of new orders to capacity), and a sudden deceleration of output, which causes a decline in the ratio of actual to "standard" productivity because of lags in hiring and firing. A simulation of the full wage-price model indicates that a 1 percentage point increase in the social security tax rate has an inflationary impact that, at its maximum, raises the rate of inflation by 0.23 percentage point two quarters after the tax increase, but that dissipates completely after ten quarters. An increase of the effective personal income tax rate by 1 percentage point has a smaller but long-lasting influence that reaches a maximum effect of 0.16 percentage point after three quarters, and continues to have a small effect even after four years, due to the lagged interaction of the wage and price equations. The statistical research is less conclusive on two issues: The "accelerationist" hypothesis can be statistically rejected but by a narrower margin than in most previous research; and the evidence does not give strong support to any aggregate measure of unemployment as an indicator of labor market tightness, including Perry's weighted unemployment rate. On both of these issues, experimentation not reported in this paper indicates that the data do not give strong signals, and there is relatively little difference in the accuracy with which several alternative hypotheses appear to fit the historical record.

Second, what caused the sustained inflation of 1968-70? The fundamental problem in 1968-69 was excess demand, which pushed the unemployment rate to a level of 3.3 percent in early 1969 and tightened labor markets as measured by unemployment dispersion and hidden unemployment. Some temporary upward price pressure also came from the direct effects of the substantial social security tax increase of 1966 and the personal tax surcharge of 1968-69. Another problem was the abrupt slowdown of out- 
put growth between mid-1968 and mid-1969, which caused a substantial drop in the ratio of actual to "standard" productivity. Easier labor market conditions in 1970 had not substantially moderated the rate of inflation at year's end because of long lags in the wage-price process.

Third, has inflation been worse in the early seventies than could have been anticipated knowing the unemployment rates that characterized the economy in the late sixties? A given official unemployment rate was associated with more inflation in the late 1960s than it was in the mid-1950s because of the increased dispersion of unemployment, so that in the long run even a 4.0 percent "full employment" rate of unemployment causes a 5 percent rate of inflation now, as compared with only a 3 percent rate of inflation in the mid-1950s.

Finally, what is the optimal policy for 1971-72? At the outset, policy makers will have the unpleasant task of choosing the particular long-run combination of inflation and unemployment they wish to achieve. To many, the inflation rate of more than 5 percent that this paper suggests may accompany a "full employment" unemployment rate of 3.8 percent is unacceptable. On the other hand, there appears to be good reason to believe that the main costs of a fully anticipated inflation are small, and that most of the political furor caused by the recent inflation has been due to its unanticipated character. If a 3.8 percent unemployment rate is the long-run goal of policy, no long-run benefit will be achieved by a "stop-go" policy that results in recessions like that of 1970. Simulations in this paper show that, even if full employment is reattained by very rapid output expansion between now and the end of 1972, the recession will have caused a loss of $\$ 100$ billion in output (at today's prices) to achieve an inflation rate that at best, in 1971-72, is only 1 percentage point less than the rate that would have obtained if the unemployment rate had been held at 3.8 percent from 1969:4 onwards. Similarly, a policy to hold the unemployment rate at its present level of about 6 percent for another two years to "beat the inflation out of the system" will cost an additional $\$ 171$ billion in real output to achieve a further reduction in the inflation rate that reaches a maximum of 1.5 percentage points but then disappears. In short, whatever the target for the unemployment rate in the long run, the best short-run stabilization strategy is to guide the economy to it as rapidly as possible and remain there permanently. 


\section{APPENDIX A}

\section{Estimation of Equations for Interest Rates, Wages, and Prices}

\section{Interest Rates}

Since an increase in the expected rate of inflation $\left(g_{p^{\circ}}\right)$ raises the nominal market interest rate $(i)$ relative to the real interest rate $(r)$, historical data on the market interest rate contain information on the formation of price expectations. If the real interest rate were constant, and if the expected rate of inflation were based completely on a weighted average of past actual rates of inflation $\left(g_{p}\right)$, the magnitude of the weight for each of the past periods $\left(w_{i}\right)$ could be estimated from the following regression equation:

$$
i_{t}=r+\sum_{i=0}^{T} w_{i} g_{p_{t-i}}+u_{t}
$$

where $u_{t}$ is the error term.

In fact, equation (A.1) provides a very poor explanation of the market interest rate in the postwar United States because the real interest rate has not been constant. While a sizable econometric model would be required to describe completely the determinants of the real rate, an adequate approximation can be developed from a simple two-equation textbook model of the economy. In the commodity market of the model, the log of per capita real output $(Q)$ is a linear function of the log of "autonomous" components of real per capita spending $(A)$, the log of real per capita income $(Q)$, the real interest rate $\left(i-g_{p^{e}}\right)$, and the log of real money balances per capita $(m=(M / p))$.

$$
\text { (A.2) } \quad Q_{t}=A_{t}+a_{Q} Q_{t}-a_{r}\left(i_{t}-g_{p_{t}}\right)+a_{m} m_{t} \text {. }
$$

In the money market, the log of real per capita money demand $(m)$ is a linear function of real per capita output, the nominal interest rate (which represents the opportunity cost of holding money), and past real per capita balances:

$$
m_{t}=b_{Q} Q_{t}-b_{i} i_{t}+b_{m} m_{t-1} \text {. }
$$


Equations (A.2) and (A.3) are, respectively, particular versions of IS and LM curves of traditional macroeconomic analysis, and they can be solved simultaneously for the nominal interest rate:

$$
i_{t}=\frac{B_{1} A_{t}-B_{2} m_{t}+B_{3} m_{t-1}+B_{4} g_{p_{t}^{e}}^{e}}{B_{5}}
$$

where

$$
\begin{aligned}
& B_{1}=b_{Q} \\
& B_{2}=1-a_{Q}-a_{m} b_{Q} \\
& B_{3}=b_{m}\left(1-a_{Q}\right) \\
& B_{4}=b_{Q} a_{r} \\
& B_{5}=b_{Q} a_{r}+b_{i}\left(1-a_{Q}\right) .
\end{aligned}
$$

In (A.4) the nominal interest rate is a function of autonomous spending components, the level of current and past real money balances, and the expected rate of inflation. Note that the coefficient of $g_{p^{e}}$ is not unity unless the demand for money is interest inelastic. Equation (A.4) can be converted into an econometric equation to estimate the $B$ parameters and the weights applied to past rates of inflation in the calculation of the expected rate of inflation. The growth rate in the consumption deflator, $g_{d}$, is used to measure inflation. It is assumed here that autonomous expenditures consist of the real per capita values of government spending on goods and services $(G)$, exports $(E)$, and the "autonomous" component of investment, which in turn is assumed to be determined (as in an accelerator model) by a distributed lag on past rates of change of real per capita private nonfarm output $\left(g_{N}\right)$. Further, eleven past values of real money balances are allowed to enter the equation to permit a more flexible lag distribution than the single lagged value in (A.4). Equations have been estimated both for the Treasury bill rate $\left(i_{T_{B} B}\right)$ and three- to five-year government bond rate $\left(i_{3 / 5}\right)$ with the following results, where in each case equations were estimated with a transformation to correct for first-order serial correlation:

$$
\begin{aligned}
& \text { (A.5) } i_{T B_{t}}=0.695+0.016(G+E)_{t}+0.345 g_{N_{L}}-0.030 m_{L}+1.16 g_{d_{L}} \text {. } \\
& \text { (0.4) } \\
& \text { (0.9) } \\
& \text { (2.8) } \quad(-1.3) \\
& \bar{R}^{2}=0.954, \text { standard error }=0.00339 \text {, } \\
& \text { standard error without lagged residual feedback }=0.00438 \text {, } \\
& \text { coefficient of first-order serial correlation }=0.494 \text {, } \\
& \text { Durbin-Watson statistic }=1.633 \text {. }
\end{aligned}
$$


(A.6) $i_{3 / 5_{t}}=0.199+0.042(G+E)_{t}+0.157 g_{N_{L}}-0.080 m_{L}+0.646 g_{d L}$

$\bar{R}^{2}=0.965$, standard error $=0.00237$,

standard error without lagged residual feedback $=0.00277$, coefficient of first-order serial correlation $=0.510$,

Durbin-Watson statistic $=1.660$.

In both cases the sample period was 1954:1 to 1969:4. The subscript $L$ denotes the sum of a series of distributed lag coefficients, with individual coefficients constrained to lie along a fourth-degree polynomial with both a level and a first derivative equal to zero in the most distant period. Individual lagged coefficients and $t$-statistics are shown in Table A-1. The sample period ends in 1969, rather than 1970, because the peculiar behavior of interest rates in 1970 is not explained well by any of the interest rate equations with which I have worked; the inclusion of 1970 observations would thus cause substantial changes in coefficients.

\section{Wages and Prices}

The individual lagged coefficients and $t$-statistics for the wage and price equations are illustrated in Table A-2. The constraints on the polynomial are identical to those in the interest rate equations. 


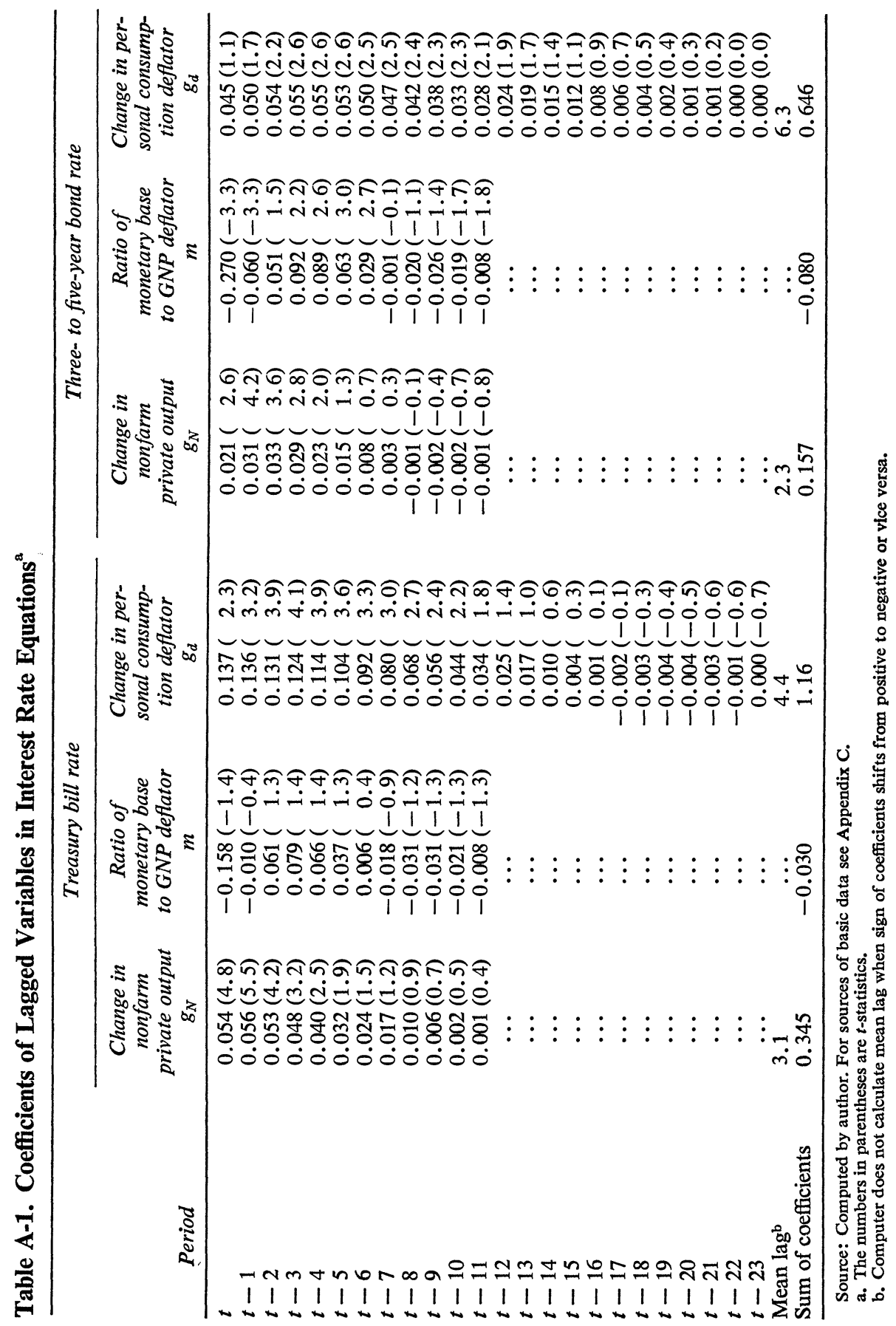


Table A-2. Coefficients of Lagged Variables in Wage and Price Equations ${ }^{a}$

\begin{tabular}{|c|c|c|c|c|}
\hline \multirow[b]{2}{*}{ Period } & \multicolumn{2}{|c|}{ Wage equation } & \multicolumn{2}{|c|}{ Price equation } \\
\hline & $\begin{array}{c}\text { Change } \\
\text { in social } \\
\text { security } \\
\text { tax rate } \\
g_{\left(1 /\left(1-T_{8}\right)\right)}\end{array}$ & $\begin{array}{l}\text { Change in } \\
\text { product } \\
\text { price } \\
\text { variable } \\
g_{p}-g_{d}\end{array}$ & $\begin{array}{c}\text { Change in ratio } \\
\text { of actual to } \\
\text { potential } \\
\text { productivity } \\
g_{q / q}\end{array}$ & $\begin{array}{l}\text { Change in } \\
\text { standard } \\
\text { unit labor } \\
\text { cost } \\
g_{v / q,}\end{array}$ \\
\hline$t$ & 1.00 & & $-0.066(-1.9)$ & $0.216(2.9)$ \\
\hline$t-1$ & -0.50 & $0.263(3.0)$ & $-0.037(-1.6)$ & $0.193(5.9)$ \\
\hline$t-2$ & -0.33 & $0.128(2.4)$ & $-0.029(-1.2)$ & $0.167(5.4)$ \\
\hline$t-3$ & -0.17 & $0.065(1.3)$ & $-0.030(-1.3)$ & $0.140(3.6)$ \\
\hline$t-4$ & $\cdots$ & $0.042(1.1)$ & $-0.031(-1.3)$ & $0.113(2.9)$ \\
\hline$t-5$ & ... & $0.036(0.9)$ & $-0.027(-1.2)$ & $0.087(2.5)$ \\
\hline$t-6$ & ... & $0.032(0.7)$ & $-0.017(-1.1)$ & $0.064(2.3)$ \\
\hline$t-7$ & $\ldots$ & $0.022(0.7)$ & $-0.006(-1.1)$ & $0.044(1.9)$ \\
\hline$t-8$ & ... & $0.008(0.7)$ & ... & $0.027(1.2)$ \\
\hline$t-9$ & ... & $\because$ & $\cdots$ & $0.014(0.6)$ \\
\hline Mean lag & ... & 2.5 & 2.4 & 2.6 \\
\hline Sum of coefficients & 0.0 & 0.596 & -0.243 & 1.062 \\
\hline
\end{tabular}

Source: Same as Table A-1.

a. The numbers in parentheses are $t$-statistics.

\section{APPENDIX B \\ Procedures Used To Generate Explanatory Variables in Forecasts}

THE ESTIMATED WAGE AND PRICE EQUATIONS, together with the expectation weights derived from the interest rate equations, are capable of generating a predicted path of wage and price change, given values of four independent variables: unemployment dispersion $(D U)$, the difference between the total and official unemployment rates $\left(U^{L}-U\right)$, the ratio of actual to potential productivity $\left(q / q^{\prime}\right)$, and the ratio of unfilled orders to capacity $(U F / K)$. In order to project the inflation that would accompany alternative paths of real output, the expected relationship between these variables and future output is estimated in this appendix.

The underlying assumptions about output growth are contained in equations (B.1) and (B.2). Using these equations, the gap $(H)$ between actual $(X)$ and potential real GNP $\left(X^{\prime}\right)$ is calculated on the assumption that 
total real gross national product grows at the same rate as real private nonfarm output $\left(Q_{t}\right)$ and potential real GNP grows at a steady annual rate of 4.3 percent throughout the forecast period.

$$
\begin{aligned}
g_{X_{t}} & =g_{Q_{t}} \\
H_{t} & =\left(X_{t}^{\prime}-X_{t}\right) .
\end{aligned}
$$

In the estimated equations presented below, the sample period is $1954: 1$ to $1970: 4$, and the subscript $L$ denotes the sum of a series of distributed lag coefficients estimated by the technique described in Appendix A. Individual lag coefficients and their $t$-statistics are presented in Table B-1. All rates of change refer to one-quarter changes except for equation (B.11), in which the variables are in the form of four-quarter changes. The first estimated equation, (B.3), relates the ratio $(J)$ of actual to trend labor force participation of secondary workers to the past history of the unemployment rate (which is assumed to enter as the inverse, $1 / U$ ).

$$
\begin{gathered}
J_{t}=0.912+0.0038(1 / U)_{L} . \\
(51.2) \quad(4.6) \\
\bar{R}^{2}=0.896, \text { standard error }=0.00509, \\
\text { standard error without lagged residual feedback }=0.00981, \\
\text { serial correlation coefficient }=0.802, \\
\text { Durbin-Watson statistic }=1.965 .
\end{gathered}
$$

The demand for private nonfarm manhours $(L)$ is estimated next in equation (B.4). It is a function of real nonfarm private output $(Q)$, with changes in $L$ assumed to react to changes in $Q$ with a lag. Because of this lag in labor demand, productivity fluctuates during cycles of output and tends to be highest (relative to its long-run trend) during periods when output growth is most rapid. Since secondary workers produce less output per manhour than primary workers, an increase in $J$ increases the number of manhours required to produce any given level of output and enters as an additional variable explaining $L$.

$$
\begin{aligned}
& g_{L_{t}}=-0.0027+0.658 g_{Q_{L}}+0.438 g_{J_{L}} . \\
& (-1.7) \quad(4.7) \\
& \bar{R}^{2}=0.808, \text { standard error }=0.00415 \text {, } \\
& \text { Durbin-Watson statistic }=2.033 \text {. }
\end{aligned}
$$

The rate of growth of private nonfarm productivity is calculated from the identity (B.5):

$$
g_{q_{t}}=g_{Q_{t}}-g_{L_{i}}
$$




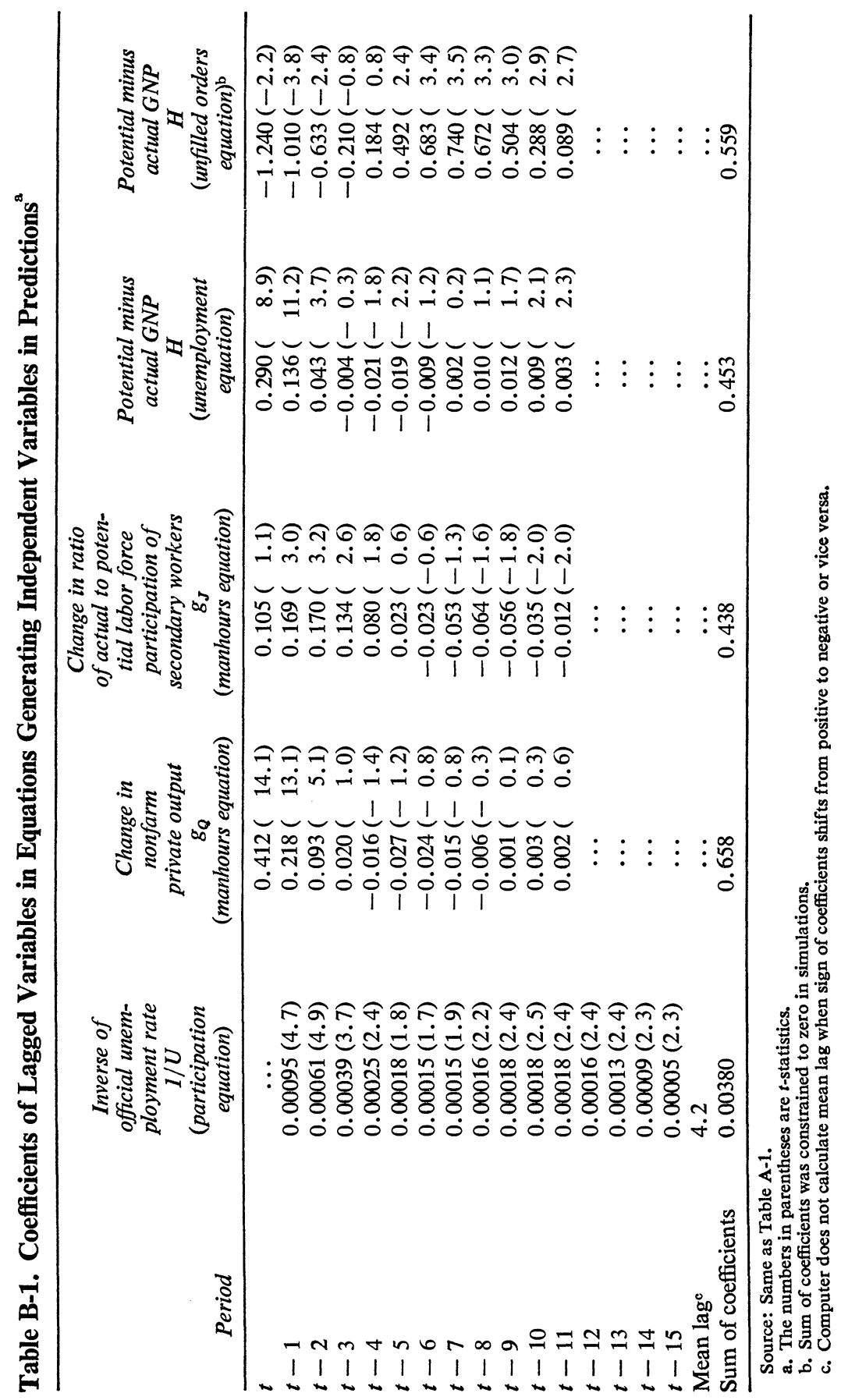


In (B.6), the potential rate of growth of manhours $\left(g_{L^{\prime}}\right)$ is calculated from the manhours equation (B.4) for a steady rate of growth of output of 1.075 percent per quarter; $g_{L^{\prime}}$ equals 0.44 percent per quarter, or 1.75 percent per year.

$$
g_{L^{\prime} t}=-0.0027+0.658(0.01075)=0.0044 \text {. }
$$

The total unemployment rate of manhours $\left(U^{L}\right)$ is calculated using (B.7), which adjusts the observed total unemployment rate at the beginning of the forecast period by each period's difference between the actual rate of growth of manhours $\left(g_{L}\right)$ and 0.0044 , their potential rate of growth.

$$
\left(1-U_{t}^{L}\right)=\left(1-U_{t-1}^{L}\right)+\left(g_{L_{t}}-0.0044\right)\left(1-U_{t-1}^{L}\right) \text {. }
$$

The level of potential productivity $\left(q^{\prime}\right)$ is computed sequentially for each quarter in (B.8), using the quarterly growth rates of potential output (0.01075) and potential manhours (0.0044) from (B.6) and a starting-point estimate of potential productivity:

$$
q_{t}^{\prime}=q_{t-1}^{\prime}(1+0.01075-0.0044)
$$

The level of actual productivity calculated in (B.5) is divided by the level of potential productivity to create the productivity ratio variable $\left(q / q^{\prime}\right)$ needed for the price equation and for predicting the unemployment rate.

The official unemployment rate $(U)$ is estimated in (B.9) as a function of productivity ratio $\left(q / q^{\prime}\right)$ and the output gap $(H)$.

$$
\begin{gathered}
U_{t}=-0.0606+0.100\left(q / q^{\prime}\right)_{t}+0.453 H_{L} . \\
(-1.3) \quad(2.0)
\end{gathered}
$$

$$
\bar{R}^{2}=0.952 \text {, standard error }=0.00237 \text {, }
$$

standard error without lagged residual feedback $=0.00400$, serial correlation coefficient $=0.783$, Durbin-Watson statistic $=1.61$.

In (B.10) unemployment dispersion $(D U)$ is related to the official unemployment rate, using a simple equation that generates predictions consistent with demographic forecasts compiled by George Perry.

$$
D U=0.4511+3.65(0.060-U) .
$$

The final equation, (B.11), explains changes in the ratio of detrended unfilled orders to capacity as a function of the past behavior of the GNP gap. As would be expected, the coefficients (see Table B-1) indicate that a reduction in the gap first raises and then reduces $U F / K$, although the net effect is a decrease. For the simulations, the net effect is constrained at 
zero. Unlike the other equations, here the dependent variable is in the form of a four-quarter change.

$$
g_{(U F / K)_{t}}=0.023+0.559 H_{L} .
$$

$$
\bar{R}^{2}=0.838 \text {, standard error }=0.0546,
$$
standard error without lagged residual feedback $=0.100$, serial correlation coefficient $=0.822$, Durbin-Watson statistic $=1.30$.

\section{APPENDIX C}

\section{Symbols and Sources of Data Used in Regressions}

THIS APPENDIX PROVIDES the definition and method of constructing certain special variables used in the regressions; a complete list of the symbols used, together with their sources; and a key to the abbreviations used to identify the sources.

\section{Newly Devised Variables}

The wage rate $(w)$. The series, "straight-time private nonfarm average hourly earnings adjusted for changes in industry mix" is constructed as a weighted average of average hourly earnings for the individual industry classifications shown below, with 1963 employment by industry used as weights. (The constant employment weights are derived from Monthly Labor Review, Volume 94 (March 1971), Table 11, page 95.) Only the manufacturing data are adjusted to remove the effects of overtime. In order to adjust for fringe benefits, the aggregated data for each quarter are multiplied by the ratio of total compensation of employees to wage and salary income as recorded in the national income accounts. The individual industries and sources of data are as follows: ${ }^{1}$

1. See "Key to Sources," pp. 157-58. 
Industry

Manufacturing (excludes the effect of overtime and is based on fixed industry weights at the three-digit level for 1959-70, and at the twodigit level before 1959)

Mining

Contract construction

Transportation and public utilities (unweighted average of Class I railroads and telephone communication)

Wholesale trade

Retail trade

Finance, insurance, real estate

Services
Source

BLS 1616/EI

EE/MLR

EE/MLR

EE/MLR

EE/MLR

EE/MLR

EE/MLR (annual data interpolated before 1964)

Assumed equal to retail trade

The nonfarm private deflator calculated with fixed weights $(p)$. The nonfarm private deflator used in the regressions is a fixed-weight average of fifteen separate expenditure deflators, weighted by 1963 expenditures. All data are from SCB. Sectors with positive weights are durable consumption, nondurable consumption, consumption of services, residential structures, nonresidential structures, producers' durable equipment, exports, federal spending on goods and services, and state and local spending on goods and services. Sectors with negative weights are imports, general government product, farm product, rest-of-world product, and household product.

Unemployment rate of hours $\left(U^{H}\right)$. Quarterly data on actual private nonfarm hours worked after 1964 were obtained from EE and SCB. Since only annual private nonfarm data are available before 1964 from this source, quarterly nonfarm private hours were interpolated from annual data using the pattern of manufacturing hours. "Potential" private nonfarm average hours per man were estimated by a trend line moving between peak quarters in average hours in 1950:4, 1955:4, and 1966:1. After 1966:1 a further adjustment was made: Since average hours were much lower in 1967-69 than a projection of the 1955-66 trend line would have predicted, a new trend line was drawn between actual average hours worked in 1966:1 and 1968:3. After 1968:3 the potential trend line was continued using the 
rate of decline in average hours per worker between 1955 and 1966. The unemployment rate of hours is then 1.0 minus the ratio of actual to "potential" private nonfarm hours.

Disguised unemployment $\left(U^{D}\right)$. Disguised unemployment is equal to the "labor reserve" divided by the civilian labor force, where the labor reserve is defined as the potential total labor force (including armed forces) minus the actual total labor force. The potential total labor force is computed separately for "primary" workers (males aged 25-54) and "secondary" workers. For each group, it is defined as the population times its potential labor force participation rate. The actual total labor force participation rate is explained in regressions using (1) a constant and a time trend in the case of primary workers, and (2) a constant, a time trend, and the ratio of secondary total employment to secondary population in the case of secondary workers. The potential labor force participation rate for each group is derived by substituting into the fitted regressions an assumed "full employment" secondary employment rate of 95.0 percent.

The ratio of unfilled orders to capacity $(U F / K)$. The ratio of unfilled orders to shipments in durable manufacturing (from BS and SCB) was multiplied by the Federal Reserve Board index of capacity utilization in manufacturing (from $\mathrm{BCD}$ ). The resulting ratio was detrended by dividing it by values along a trend line extended between peaks in 1952:3, 1956:3, and 1966:4.

Potential private nonfarm productivity $\left(q^{\prime}\right)$. A trend line was extended between values of actual productivity in 1950:4, 1955:2, and 1966:1.

\section{Symbols and Sources}

$\begin{array}{lll}\text { Symbol } & \text { Name of Variable } & \text { Source } \\ \text { CMH } & \text { Compensation per manhour; } & \text { PWP } \\ & \text { overtime and industry mix adjustment } & \text { RJG, 1969 } \\ c & \text { Consumer price index } & \text { BS/SCB } \\ c^{e} & \text { Expected price variable } & \text { RJG, 1970 } \\ d & \text { Personal consumption deflator } & \text { SCB } \\ d^{e} & \text { Expected rate of inflation in } d, \text { weights } \\ & \text { used for calculations listed in Table A-1 } \\ D_{G} & \text { Guidepost dummy; equals 0.25 in } \\ & 1962: 1,0.50 \text { in 1962:2, 0.75 in }\end{array}$


$1962: 3,1.0$ in $1962: 4$ to $1966: 4,0.75$ in $1967: 1,0.50$ in $1967: 2,0.25$ in $1967: 3$, and 0.0 in other periods

DU Unemployment dispersion index

GLP

$E \quad$ Real exports per capita

SCB, BS/ERP

Percentage rate of growth

G

$G$ Real government spending per capita, both federal and state and local

Potential minus actual GNP

SCB, BS/ERP

Rate on three- to five-year government bonds

$i_{T B} \quad$ Rate on Treasury bills

$J$

Ratio of actual to potential labor force participation of secondary workers

$L \quad$ Private nonfarm manhours

BCD

$i_{3 / 5}$

Monetary base per capita divided by the GNP deflator

$N \quad$ Nonfarm private output per capita

Nonfarm private deflator, calculated with fixed weights

$p^{e}$

Expected price variable, explained in context

Nonfarm private output per manhour; equals $Q / L$

$q^{\prime} \quad$ Potential value of $q$

$Q \quad$ Nonfarm private output

App. C

SCB

$T_{e} \quad T_{\varepsilon}$ plus federal plus state and local per-

SCB sonal tax and nontax payments divided by personal income

$T_{8} \quad$ One-half of federal plus state and local so-

SCB cial security tax revenue divided by total wage and salary payments

$U \quad$ Official unemployment rate

BS/SCB

$U^{*} \quad$ Weighted unemployment rate

GLP

$U^{D}$

Disguised unemployment rate

App. C

$U^{H}$

Unemployment rate of hours

App. C 


$\begin{array}{lll}\text { Symbol } & \text { Name of Variable } & \text { Source } \\ U^{L} & \text { Total unemployment rate of manhours; } & \\ & \text { equals } U+U^{H}+U^{D} & \\ V & 11.0 \text { times nonagricultural job openings } & \text { BCD } \\ & \text { divided by civilian labor force } & \\ w & \text { New fixed-weight wage index for private } & \text { App. C } \\ & \text { nonfarm economy } & \text { SCB }\end{array}$

Key to Sources

App. C Earlier pages in this appendix

BCD Business Conditions Digest, various issues

BLS 1616/EI Bureau of Labor Statistics Bulletin 1616, Summary of Manufacturing Production Workers Earning Series, 1939-68, updated with current data from Economic Indicators

BS/SCB U.S. Office of Business Economics, Business Statistics, 1969, for data to $1968: 4$, and various issues of the Survey of Current Business for subsequent data

BS/ERP Same as BS/SCB, but with subsequent data from Economic Report of the President, various issues

EE/MLR Bureau of Labor Statistics Bulletin 1312-6, Employment and Earnings Statistics for the United States, 1909-68, updated with current data from Monthly Labor Review

GLP Data provided by George L. Perry, as used in his paper, "Changing Labor Markets and Inflation," Brookings Papers on Economic Activity (3:1970), pp. 411-41

PWP Bureau of Labor Statistics quarterly mimeographed release, "Productivity, Wages, and Prices"

RJG, 1969 Robert J. Gordon, "Problems in Predicting the Rate of Inflation," paper presented to the Econometric Society meetings, New York, December 30, 1969

RJG, 1970 Robert J. Gordon, "The Recent Acceleration of Inflation and Its Lessons for the Future," Brookings Papers on Economic Activity (1:1970), pp. 8-41 
SL

Mimeographed releases from the Federal Reserve Bank of St. Louis

SCB

1966 Supplement to the Survey of Current Business (The National Income and Product Accounts of the United States, 1929-65: Statistical Tables) for data to 1963:4, and various issues of the Survey of Current Business for subsequent data 


\section{Comments and Discussion}

William Brainard: Gordon has presented a provocative paper and introduced two interesting innovations: his new wage variable and his measure of price expectations. The use of a fixed-weight wage index, which Gordon has constructed, seems desirable on both theoretical and empirical grounds. Basically, we believe that the excess demand variables affect wages differently from changes in the industry mix of employment, so a variable purged of mix changes is useful for the assessment of the effect of excess demand. Furthermore, it seems reasonable to suppose that a change in total compensation due to changes in the industry mix has a different effect on prices from a change in compensation arising from the wage rate. In particular, it is not clear why a change in the industry mix by itself should lead to greater pessimism about the rate of inflation, given the course of wage rates. In Gordon's price equation, however, for a lag extending four quarters back, compensation appears to be roughly as important as changes in the adjusted wage rate. If mix effects are in fact largely responsible for the movement in the ratio of compensation per manhour to the wage rate, its coefficient in this equation is likely to reflect the relatively procyclical behavior of high-wage industries, and its significance should not be taken to indicate a causal relationship between increases in average compensation and the rate of inflation.

Gordon stresses the use of a new price expectations variable. This variable is constructed by using weights on past price changes coming from a regression that relates nominal rates of interest to autonomous spending components, the level of current and past real money balances, and past rates of inflation. This is an interesting way to proceed and may well remove some of the simultaneous equation bias usually thought to be present when wages are regressed on prices. The fact that the coefficient on price 
expectations on the interest rate equation is approximately 1.2 suggests, however, that some of the problem remains, since according to the theoretical model Gordon uses in its specification, it should be less than 1 . When the constructed price expectations series is used in the wage equation instead of the CPI, its coefficient is larger, but no more significant. When lagged values of the growth rate in the nonfarm private deflator are included in the regression, however, the quantitative importance of the sophisticated price expectations variable virtually disappears: Lag values of the deflator, which are supposed to measure what Gordon calls the "product price effect," get virtually all the weight. Taken at face value, these results indicate that it is producers' rather than consumers' expectations that matter.

Gordon utilizes his preferred wage and price equations to derive a longrun relationship between unemployment and inflation. He assumes-properly, in my view - that the ratio of unfilled orders to capacity, and of actual to standard productivity, is independent of the unemployment rate in the long run. Presumably, most of the correlation between these variables and unemployment during the sample period reflects mutual correlation with the cycle, rather than some long-run causal connection. For similar reasons, I believe that the long-run impact of unemployment on the rate of inflation that works through the remaining variables in his equation ( $D U, U^{D}, U^{H}$, and price expectations) is likely to be overstated. First, Gordon estimates a 3.65 point increase in dispersion for a 1 point reduction in unemployment; but a good case can be made for thinking that in the long run the level of dispersion would be independent of the level of unemployment. As its significant coefficient in Gordon's wage equation indicates, recent changes in dispersion may well have shifted the Phillips curve, but it requires an additional belief in the long-run connection between dispersion and unemployment to infer that the curve is steeper than it otherwise would be. Second, as Gordon recognizes, the large coefficients on his labor market demand variables are likely to reflect the fact that they are proxies for some other cyclical variables. If so, even if they respond to unemployment in the long run as much as Gordon estimates, the long-run effect on wages and prices of such a response is probably overestimated. Third, all of the price variables Gordon tries for price expectations are subject to the usual complaint that prices and wages may be jointly influenced by some other cyclical variables and that the price coefficient in the wage equation or the wage coefficient in the price equation is likely to embody simul- 
taneous equation bias. Perhaps it should also be noted that forming the price expectations variable using the consumer price index rather than the personal consumption deflator would have resulted in a much smaller estimated difference between the slopes of the short- and long-run Phillips curves.

Gordon pays unusual attention to the effect of direct taxes on pretax wage rates. Although his regressions provide useful information about the short-run impact of tax changes on wages, they provide a very weak basis for deciding whether labor or capital bears the tax burden. An increase in an employment or income tax is effectively an upward shift in the pretax labor supply schedule, which in the usual textbook treatment would result in a lower level of "equilibrium" employment and a higher equilibrium level of the pretax real wage rate (assuming that supply and demand are not perfectly inelastic). In the context of the Phillips curve, such a shift would mean that in the long run a lower level of unemployment, and a higher rate of change in wages, would be associated with a given level of employment; or alternatively, that given rates of unemployment and wage increase would be associated with a lower level of employment. These effects are permanent and remain as long as there is a real tax wedge between what employers pay and what employees get. Now Gordon uses a rather peculiar definition of burden in his discussion. It is true that if labor cares only about its share, and not how much it gets, then under his assumptions, the "burden" of a tax increase is borne entirely by labor in the long run. But his results tell us nothing about who bears the burden of a reduction in employment and output that would be associated with given rates of unemployment and wage increase, in either the short or the long run.

Thomas Juster: First, let me commend Gordon for the attempts he makes here to adjust the basic data in order to get numbers that accord more closely to the analytic concepts in his model. The profession does too little of this. The focus of this model is the role of price expectations in wage determination and subsequent inflation. Does the model in fact capture the role of expected prices? I am one of the critics noted in the paper who objects to the use of distributed lags on past changes to measure price expectations on the simple grounds that the process is more complicated than that. To rely on distributed lags is to say that people are incapable of making use of new information or of information that does not grow out of past be- 
havior of a particular statistical series. The Livingston series is the only one presented that is not generated by the lag process. Like Gordon, I would eliminate the Livingston data from the list of legitimate estimates of price expectations, but for reasons different from his. The Livingston data are a collection of economists' judgments about what will happen to prices-not the price expectations of people who bargain for wages or make labor force decisions. Some data collected by the Survey Research Center come closer to measuring the right price expectations, although they probably do not cover the period Gordon deals with. I expect this series would not fit the data as well as the series being used. But I would still prefer it because it fits the analytic concept one is trying to measure.

Another aspect of the price expectations measure that I do not care for is its implicit assumption that the lag structure is constant. I would expect that a greater perception of inflation would affect the reaction to it. And I would also guess that when inflation is 2 percent a year no one cares much, but when it is 5 and 6 percent a year, people notice it; and this difference affects the way inflation influences their wage demands. I would also expect different reactions when inflation was speeding up than when it was slowing down. One could try to test for differences in the lag structure at different periods; but I doubt that there are enough degrees of freedom in the data to permit this. Several different tests were run on the size of the coefficient for price expectations, all fitted to the whole period. But looking at the size of the standard errors, I find it difficult to differentiate among them. I raise these questions about the uncertainty surrounding Gordon's estimate of price effects because his results rest so heavily on the size of the coefficient of the price expectation term and the lag structure that is built into it.

My final observation is that I do not think that the erratic behavior of the series on compensation per manhour is as much a result of the overlapping years and year-end adjustments as Gordon does. There is a lot of what appears to be regular cyclical movement in the series, but I do not know what causes it.

R. J. Gordon: Regarding the interpretation of the 0.6 coefficient on the ratio of total compensation per manhour to my wage index, a 1 percent increase in the ratio increases prices by less than 1 percent because some changes in the ratio reflect shifts in industry mix or measurement error, which do not influence price determination. The 0.6 percent price increase caused by a 1 
percent increase in the ratio reflects, I believe, the influence on price of overtime, executive compensation, and other payments that are included in the numerator of the ratio but not in the denominator. I agree with Juster that price expectations may adjust to experience with variable lags, but I feel that the data are inadequate to isolate this effect. I disagree with Brainard's interpretation of the product price variable. The different lags on the two price variables had been freely estimated, and they suggested quite separate responses, with an impact of the product price differential having a mean lag of 2.5 quarters and a quite separate impact of consumer prices on expectations having a mean lag of 4.4 quarters.

\section{General Discussion}

Much of the discussion focused on Gordon's price expectations variable. Questions arose both about the way expectations had been estimated by Gordon and about the role expectations should be expected to play in wage determination. Franco Modigliani was skeptical about the long lags Gordon associated with the price expectations variable. He found no analytical reason to believe that people contracting currently for wages would be worrying about prices in the distant future. In his view, reasonably current rather than distant price changes might influence wages. He reported that in his own empirical research, which distinguished between a more highly unionized and a less unionized sector of the labor market, measures of price expectations based on a long distributed lag of past price changes turned out to be consistently insignificant or to have the wrong sign, or both.

James Duesenberry and others argued that expectations about future price increases were not well represented by long moving averages of past price changes; it seemed unreasonable to believe that people form their views about the future simply and mechanically by looking backward. Charles Schultze wondered specifically how much Gordon's results were influenced by the sample period of the equations. He conjectured that, if the equations had been fitted back through the Korean war, the lags on the price expectations variables would be shortened. Like Juster, Schultze pointed to the possibility of a variable lag. He felt that the duration and persistence of inflation in recent years has had a dominant influence on price expectations. 
Arthur Okun and George Perry agreed with Brainard that Gordon's results showed that producers' rather than consumers' price expectations affected wages. They pointed out that this had different implications for some types of policy. Excise taxes, for example, would have no subsequent effect on wages on this view, whereas they would have an impact if the price effect operated on labor supply. Duesenberry noted the various ways that product prices could operate on wages; he felt that both types of price effects were relevant and wanted the two separated carefully.

Paul Samuelson stressed that the true position and shape of the long-run Phillips curve depended on the size of a great many partial derivatives, which could not be determined with any precision. The resulting estimate of the curve is subject to enormous uncertainty. He was concerned that research on the tradeoff in the Brookings panel may have been excessively influenced by the stubborn behavior of prices and wages in 1970 . Since prices and wages rose faster in 1970 than expected, Gordon got better results in explaining the year by relying on longer lags and consequently on larger price expectation coefficients. In response, Gordon pointed out that the improvements in this year's paper were equally valid in explaining the period ending in 1968; and equations fitted to the period ending in 1968 gave good forecasts of 1969-70, as illustrated in Figure 3.

Samuelson felt that intuition and insight gave different economists different answers; his own intuition stressed changes in society's determination to alleviate the human misery of unemployment. He wondered whether the impact of unemployment on wage determination had not shifted over time. As our society has become more humane in liberalizing our systems of unemployment compensation and welfare, the Phillips curve may inevitably have shifted from where it would have been if joblessness were an even more desperate problem for individuals.

Perry was concerned about the refinements that Gordon had made in the labor market variables. On theoretical grounds, he found the concepts of disguised unemployment and of the unemployment of hours unconvincing as major determinants of labor market tightness, although they might have a place as refinements to a broad unemployment measure. He also felt that the particular way these variables were formed was open to question and may have given a spurious fit to recent inflation. Specifically, he was skeptical of the two-year disruption Gordon imposed in his construction of an hours trend and the negative values that Gordon attributed to disguised unemployment in recent years and, most of all, of the growing negative values 
in 1970. Granting that these variables have been serving as proxies for aspects of labor market tightness other than those they were designed to measure, the fact that they took over the whole explanation rather than supplementing an aggregate unemployment variable made it very hard to interpret the results in terms of an unemployment-inflation tradeoff. The tradeoff interpretation had to rest on the casual relations between these proxy variables and the unemployment rate presented in Gordon's appendix, with little evidence on what that relation should be since it was unclear what the variables were proxies for.

Gordon reemphasized that the unemployment of hours and disguised unemployment variables were standing as proxies for unmeasurable changes in excess labor demand. It was not surprising that the aggregate unemployment rate was an inaccurate measure of excess demand in a year like 1969 when a large part of the increase in employment was made possible by an increase in the labor force participation rate. The two-year interruption of the trend in hours per man was imposed because of a mysterious drop in 1966-68 of almost one hour per week, far more than the postwar downtrend in hours would imply. This drop was treated by ad hoc procedures pending detailed microeconomic research to explore its cause.

Several participants expressed interest in Gordon's explorations with tax variables. Joseph Pechman pointed out that the personal tax measure Gordon used, the ratio of taxes to income, rose over time as a result of progressivity when incomes increased even when the tax laws were unchanged; he found it implausible that this could have an impact on before-tax wages. Arthur Okun was puzzled by the way the two parts of the social security tax operated. According to Gordon's estimates, employers were initially stuck with their share of the tax, but they managed to get it unstuck over time and shift it all back to the employees. Meanwhile, however, the workers managed to shift a small portion of their share onto employers. It didn't seem plausible that nominal compensation ultimately reflected a small part of the employees' share but none of the employers' share.

Gordon agreed with both these comments. In future research a more satisfactory personal tax rate series should be devised and if the coefficient on the employers' tax had to be constrained, it would make more sense to constrain the total effect to be identical to that of the employee tax.

Both Modigliani and Duesenberry thought that future research on wages should separate the unionized and nonunion sectors of the economy. Modigliani reported good results in tracking 1970 with a two-sector wage 
model that separated union and nonunion wages. In the union sector, the number of contract negotiations was an important variable. This was probably one reason that the two-sector model did so well in explaining 1970, which saw an abnormally large number of negotiations. In the nonunion sector, rises in the minimum wage had an important impact on wages, while social security taxes had less of an influence than in the union sector. Duesenberry thought that the wage settlements in 1970 and 1971 were being influenced to a significant degree by previous settlements, even though the underlying economic conditions had changed, and that this created an unusually long lag in the slowing of average wage changes during the current period of high unemployment. He thought it hopeful for the outlook that the current cycle of wage settlements essentially would be concluded in 1971. 